\title{
Evaluating Domestic Hot Water Distribution System Options With Validated Analysis Models
}

E. Weitzel and M. Hoeschele Alliance for Residential Building Innovation 


\section{NOTICE}

This report was prepared as an account of work sponsored by an agency of the United States government. Neither the United States government nor any agency thereof, nor any of their employees, subcontractors, or affiliated partners makes any warranty, express or implied, or assumes any legal liability or responsibility for the accuracy, completeness, or usefulness of any information, apparatus, product, or process disclosed, or represents that its use would not infringe privately owned rights. Reference herein to any specific commercial product, process, or service by trade name, trademark, manufacturer, or otherwise does not necessarily constitute or imply its endorsement, recommendation, or favoring by the United States government or any agency thereof. The views and opinions of authors expressed herein do not necessarily state or reflect those of the United States government or any agency thereof.

Available electronically at http://www.osti.gov/scitech

Available for a processing fee to U.S. Department of Energy and its contractors, in paper, from:

U.S. Department of Energy

Office of Scientific and Technical Information

P.O. Box 62

Oak Ridge, TN 37831-0062

phone: 865.576 .8401

fax: 865.576.5728

email: mailto:reports@adonis.osti.gov

Available for sale to the public, in paper, from:

U.S. Department of Commerce

National Technical Information Service

5285 Port Royal Road

Springfield, VA 22161

phone: 800.553 .6847

fax: 703.605.6900

email: orders@ntis.fedworld.gov

online ordering: http://www.ntis.gov/ordering.htm 


\title{
Evaluating Domestic Hot Water Distribution System Options With Validated Analysis Models
}

\author{
Prepared for: \\ The National Renewable Energy Laboratory \\ On behalf of the U.S. Department of Energy's Building America Program \\ Office of Energy Efficiency and Renewable Energy \\ 15013 Denver West Parkway \\ Golden, CO 80401 \\ NREL Contract No. DE-AC36-08GO28308 \\ Prepared by: \\ E. Weitzel and M. Hoeschele \\ Alliance for Residential Building Innovation \\ Davis Energy Group, Team Lead \\ 123 C Street \\ Davis, CA 95616 \\ NREL Technical Monitor: Stacey Rothgeb \\ Prepared under Subcontract No. KNDJ-0-40340-04
}

September 2014 
The work presented in this report does not represent performance of any product relative to regulated minimum efficiency requirements.

The laboratory and/or field sites used for this work are not certified rating test facilities. The conditions and methods under which products were characterized for this work differ from standard rating conditions, as described.

Because the methods and conditions differ, the reported results are not comparable to rated product performance and should only be used to estimate performance under the measured conditions. 


\section{Contents}

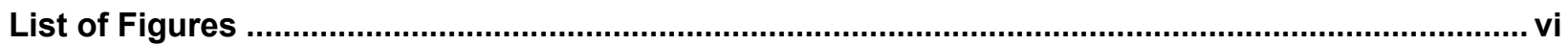

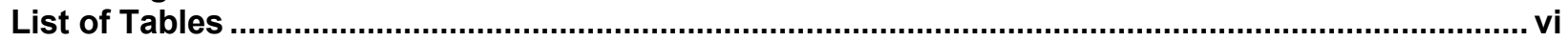

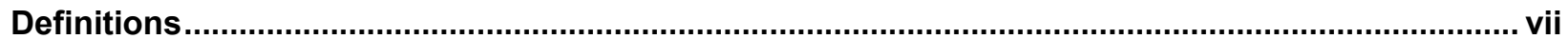

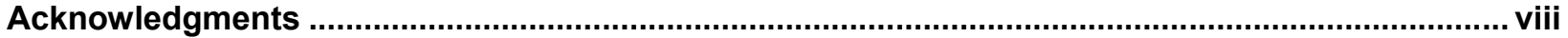

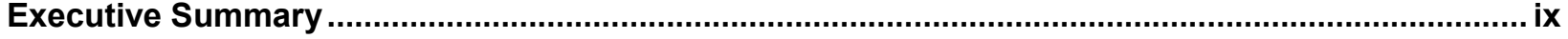

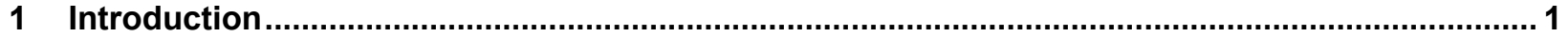

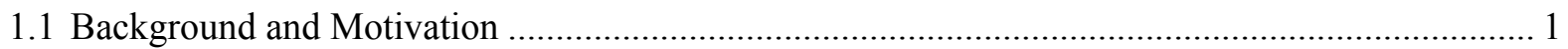

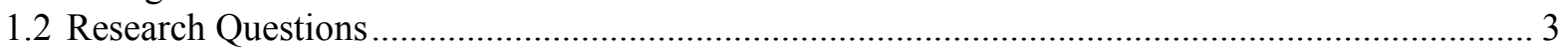

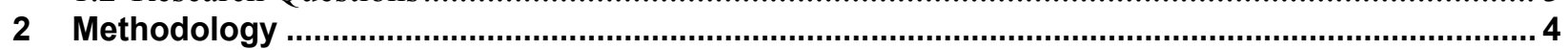

2.1 Building America Domestic Hot Water Event Schedule Generator .......................................... 6

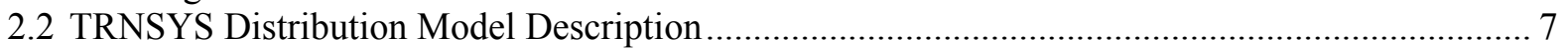

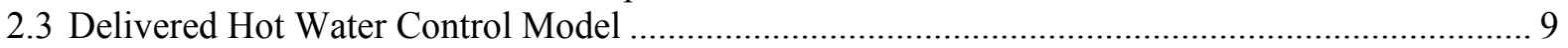

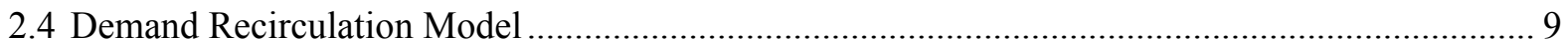

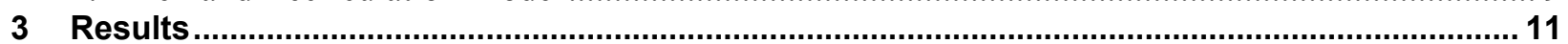

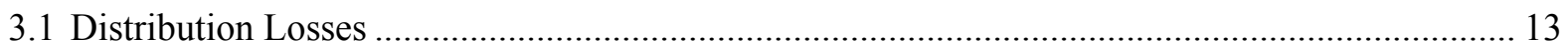

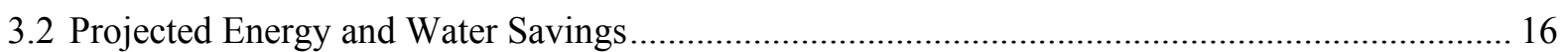

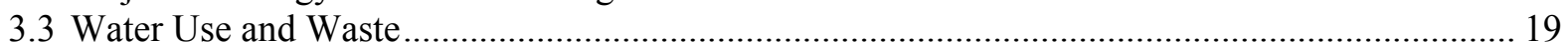

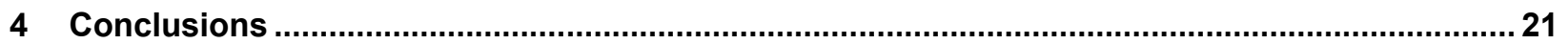

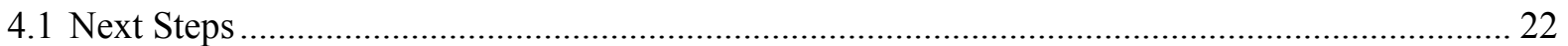

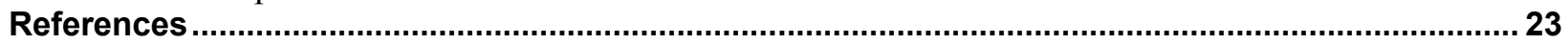

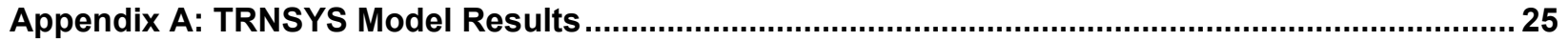

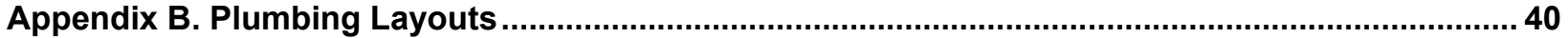




\section{List of Figures}

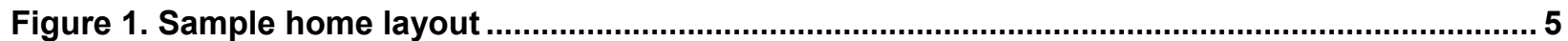

Figure 2. Sample distribution layout

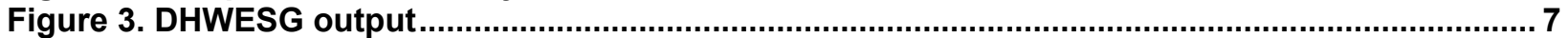

Figure 4. Representation of TRNSYS model configuration ......................................................... 9

Figure 5. System ranking by annual water heater energy use and waste (2 person) ...................... 12

Figure 6. System ranking by annual water heater energy use and waste (4 person) ...................... 13

Figure 7. System ranking by percent distribution loss of total water heater energy use ................. 15

Figure 8. Insulation impact on distribution loss percent of annual water heater energy use .......... 16

Figure 9. Variation in distribution loss percent of useful energy delivered by climate and

installation quality

Figure 10. Hot water use (per person, per day) by climate and distribution type ............................ 19

Figure 11. Water waste (as a fraction of useful water delivered) by climate and distribution type 20

Figure 12. Trunk and branch distribution layout, basement ........................................................41

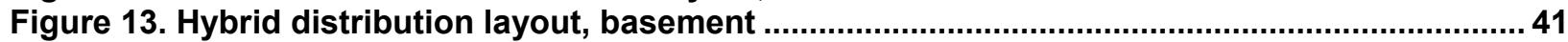

Figure 14. Home run distribution layout, basement ................................................................ 42

Figure 15. Short run-out recirculation distribution layout, basement ........................................... 43

Figure 16. Long run-out recirculation distribution layout, basement............................................. 43

Unless otherwise noted, all figures were created by the ARBI team.

\section{List of Tables}

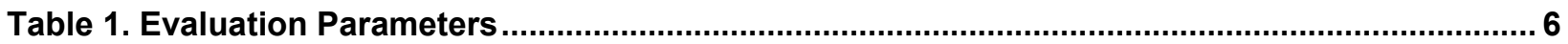

Table 2. Range of Distribution Losses as a Percentage of Total Water Heater Annual Energy Use 14 Table 3. Distribution Systems Savings in Energy, Distribution Loss, Water Use, and Water Waste

Relative to Base Case, Averaged Over Climates and Occupancy Levels ................................... 17

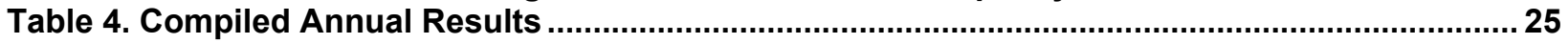

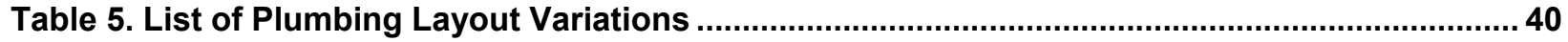

Unless otherwise noted, all tables were created by the ARBI team. 


\section{Definitions}

$\begin{array}{ll}\text { ARBI } & \text { Alliance for Residential Building Innovation } \\ \text { BEopt } & \text { Building Energy Optimization model } \\ \text { DHW } & \text { Domestic Hot Water } \\ \text { DHWESG } & \text { Domestic Hot Water Event Schedule Generator } \\ \text { HWSIM } & \text { Hot Water Simulation software } \\ \text { LBNL } & \text { Lawrence Berkeley National Laboratory } \\ \text { NAHB } & \text { National Association of Home Builders } \\ \text { NREL } & \text { National Renewable Energy Laboratory } \\ \text { PEX } & \text { Cross-Linked Polyethylene } \\ \text { TRNSYS } & \text { TRaNsient System Simulation program }\end{array}$




\section{Acknowledgments}

We would like to acknowledge the support and contributions of Jeff Maguire (National Renewable Energy Laboratory), Greg Barker (Mountain Energy Partnership), Jim Lutz (Lawrence Berkeley National Laboratory), Gary Klein (Gary Klein and Associates), Jeff Thornton (Thermal Energy Simulation Specialists), Hugh Henderson (CDH Energy), and Carl Hiller (Applied Energy Technology). This project builds upon their prior efforts in driving domestic hot water (DHW) research studies, collecting valuable lab and field data, and developing and demonstrating the improved distribution system simulation models. 


\section{Executive Summary}

While water heater performance is well characterized, DHW distribution system impacts on energy loss and water waste have only recently been studied in detail. A developing body of work is forming that provides for more data on DHW consumption, water use behaviors, and energy efficiency of various distribution systems. Concurrent models in HWSIM (Hot Water Simulation Program, Davis Energy Group) and TRNSYS (Transient System Simulation Program, TESS) have been developed to analyze distribution system performance. These high fidelity pipe models have been validated using both laboratory and field data. More recently a full distribution system developed in TRNSYS has been validated using field monitoring data and then exercised in a number of climates to understand climate impact on distribution performance. This study builds upon previous distribution model work to evaluate differing distribution systems and the sensitivities of water heating energy and water use efficiency to variations of climate, load, distribution type, insulation, and compact plumbing practices.

Overall 124 different TRNSYS models were simulated and results compiled. The base case, an uninsulated trunk and branch system is best improved in terms of annual energy consumption by insulating and locating the water heater central to the use points. Demand recirculation systems are not projected to provide significant energy savings and in some cases increase system energy consumption. Water use is most efficient with demand recirculation systems, followed by the insulated trunk and branch system with a centrally located water heater. Compact plumbing practices and insulation levels have the most impact on energy consumption (energy savings of $2 \%-6 \%$ for insulation and $3 \%-4 \%$ per 10 gal of enclosed volume reduced). Of the configurations evaluated, distribution losses account for $13 \%-29 \%$ of the total water heating energy use, with compact, insulated low-load systems having the least distribution losses. Water use efficiency ranges from $11 \%-22 \%$, with uninsulated home run systems and noncompact plumbing practices accounting for the most water waste.

The results of this work are useful in informing future development of water heating best practices guides as well as more accurate (and simulation time efficient) distribution models for annual whole-house simulation programs. Future work is needed to better characterize many of the inputs to these models (plumbing configurations and layouts, usage patterns, impact of high efficiency hot water fixtures and appliances), as all these factors can have a significant impact on water heating energy use and water waste. 


\section{Introduction}

Domestic hot water (DHW) systems have four areas of energy transfer: water heater inefficiency, water heater standby losses, distribution system losses, and energy consumed at the end use point. The losses at the water heater, including standby energy consumption, efficiency of the heating source, and delivery have been well studied and characterized. The distribution systems have only recently been studied and evaluations include the losses attributed to piping elements and useful hot water thresholds, which combine to what is called structural waste. There have also been several recent studies into the behavioral patterns of hot water usage (Lutz and Melody 2012; Sherman 2014); however, the behavioral and structural wastes have been difficult to decouple. This study aims at determining the impact of differing distribution system parameters on structural component of waste, to provide insight into how distribution systems affect total water heating energy and water use efficiency.

\subsection{Background and Motivation}

In recent years, many studies have been conducted to better understand the performance of DHW distribution systems. In 2008, Davis Energy Group released an updated Hot Water SIMulation software (HWSIM) to analyze DHW system performance at a higher resolution than previous hourly analysis models (Springer et al. 2008). The original HWSIM allowed for an input of seven distinct daily water heater draw schedules per month, applied pipe heat capacitance and material-dependent convective and radiant terms to the heat transfer model, and utilized a simple tank water heater with a user-specified energy factor to supply the distribution system. In 2011, HWSIM was further updated with high resolution, multinodal atmospheric gas storage and gas tankless water heating models. HWSIM reduced the input draw schedules to one representative day per season to expedite simulation performance with the higher fidelity water heating models (Kosar et al. 2012). HWSIM was validated with laboratory data collected by Carl Hiller from Applied Energy Technology (Hiller 2006) testing various piping materials under different flow rates and environmental conditions.

On a parallel track to the HWSIM enhancements, the National Renewable Energy Laboratory (NREL) was evaluating a typical trunk and branch distribution model for the Building America benchmark home using TRNSYS (Maguire et al. 2011). TRNSYS is a time-based discrete simulation software that analyzes models assembled from individual modeling elements. The pipe element model used in the NREL analysis used a fixed pipe heat transfer coefficient and did not account for the heat capacity effects that affect cold-start conditions and relaxation between draws. The results from the study were implemented in the Building Energy Optimization Model $\left(B E o p t^{\mathrm{TM}}\right)$, with the exception that correction factors are applied to the daily hot water volume, house internal heat gain (from pipe losses), additional pumping energy, and the change in recovery load of the water heater (Wilson et al 2014) based on different distribution systems. The correction factors were determined from runs generated by the original HWSIM that evaluated different distribution systems in different climates (DEG 2006).

In 2011 TRNSYS updated a pipe model with dynamic exterior surface convective and radiant heat transfer based on material properties, fluid properties, and environmental conditions. In a 2013 Building America study (Backman and Hoeschele 2013), Davis Energy Group used the 2006 Hiller lab data to validate the new TRNSYS pipe model. The distribution system from the Maguire NREL study was enhanced with the new pipe element model and adjusted to match the 
distribution layout in an NREL monitored project (Solar Row in Boulder, Colorado), where detailed distribution system flow and temperature measurements were completed (Backman and Hoeschele 2013). The model was then validated with the Solar Row data to drive the TRNSYS model and was shown to be very robust in terms of observed distribution losses and energy consumption relative to monitored data over a several month period when monitoring data were available.

With all these successive enhancements to distribution system models, the next step is to analyze various distribution systems and determine the range of performance on a set of varying factors. Driving these models are annual draw schedules generated by a spreadsheet utility, domestic hot water event schedule generator (DHWESG) developed in 2010 by NREL (Hendron and Burch 2008).

The DHWESG utility was developed using data from two studies conducted by Aquacraft (Aquacraft 2008; Mayer and DeOreo 1999), one from a large study that measured whole-house water usage and the other measured discrete water draw events in a sample of 20 households. Lawrence Berkeley National Laboratory (LBNL) (Lutz and Melody 2012) compiled detailed high-resolution hot water usage data from numerous studies, suggesting that there is a wide variation in usage and draw patterns, both between households and within households from day to day. The high variability in usage patterns presents a particularly difficult challenge in trying to compare alternative distribution system types without completing thousands of simulation runs. In an effort to better understand use patterns, LBNL developed a database where researchers can input disaggregated end use data from various monitoring efforts.

A more recent study conducted by Advanced Residential Integrated Energy Solutions (Henderson and Wade 2014) monitored five homes near Syracuse, New York, where thermocouples were applied to each plumbing run-out line to disaggregate flow in a more nonintrusive and economical manner. In another monitoring study of disaggregated uses in 19 homes conducted by LBNL and evaluated by ShowerStart, analysis was performed to separate behavioral waste from structural waste. The study found behavioral waste to be between 38 and 56 seconds after the temperature has been reached (Sherman 2014). ${ }^{1}$ These data, along with the data collected by LBNL, will ultimately help refine assumptions of hot water usage patterns.

The Alliance for Residential Building Innovation (ARBI) team worked with the National Association of Home Builders (NAHB) Home Innovation Research Labs to obtain a snapshot of current regional and national plumbing practice based on new homes built during 2011. Based on information provided on more than 9,000 homes built in the United States, the data suggest that currently $60 \%$ of single-family homes use cross-linked polyethylene (PEX) for distribution plumbing, while $\sim 25 \%$ use chlorinated polyvinyl chloride and the rest use copper. Of the homes using PEX, nearly $40 \%$ are plumbed as trunk and branch systems, $17 \%$ in a home run configuration, and $\sim 5 \%$ as zone or hybrid (combining a trunk feeder line with remote manifolds). (In $\sim 40 \%$ of the homes, the exact plumbing system type was not represented.)

From these findings in the NAHB data, PEX was assumed for all distribution systems modeled and a representative single-family home is used for constructing different plumbing layout

\footnotetext{
${ }^{1}$ Identified by the time after hot water was reached and the observed throttling back flow to the desired temperature.
} 
configurations. This type of data is valuable in identifying regional and national construction practices. More refined data on actual documented plumbing layouts (Kosar et al. 2012; Lutz 2008) are critically needed to characterize actual installed plumbing systems. Foundation data from NAHB were also used to inform the typical house construction analyzed in various climates in terms of water heater location (basement or garage).

\subsection{Research Questions}

The primary objective of this project is to expand upon the previously validated TRNSYS DHW distribution system model by evaluating the impacts on energy and water use for different distribution system layouts, climates, and loads. This parametric study, although limited in scope, will assess sensitivity of varying factors of the distribution system to overall hot water usage and contribute to the developing body of knowledge that will ultimately inform a comprehensive hot water design guide.

The research questions that will be addressed are:

1. What is the expected range in distribution losses (as a fraction of water heater recovery load) as a function of distribution system configuration, climate, and hot water usage pattern?

2. What are the realistic savings that can be realized through measures such as insulating all piping or improving distribution system design?

3. What are the projected water use/waste implications of the various scenarios simulated?

4. Where are better data needed to improve the characterization of the "hot water system" based on the observed sensitivities in the modeling study? 


\section{Methodology}

In this study, systems were evaluated in a sample of representative climates and states of high growth according to information presented on U.S. Census Bureau website in 2013. All locations evaluated are listed in the 10 fastest growing states, and cover cold (Chicago, Illinois, and Denver, Colorado), mixed-humid (Atlanta, Georgia), hot-humid (Houston, Texas) and hotdry (Phoenix, Arizona) climates.

While the plumbing materials were not varied in this study, the location of the system was varied by climate in a decision informed by data supplied from the NAHB on current practices. According to the NAHB, the majority of single-family homes in locations encompassing Chicago and Denver are being constructed with full basements, while locations encompassing Atlanta, Houston and Phoenix are constructed on slab foundations. It is assumed for homes with full basements, that the water heater would be located in the basement, with the distribution system routing beneath the floor of the living areas. For homes constructed on slab, it is assumed the water heater would be located in the garage, with the distribution system extending into the attic and down through the interior walls to service the fixtures.

The model used as a starting point for this study was constructed using a representative benchmark home described in the NREL study (Maguire et al. 2011) and is shown in Figure 1. The home was modeled in BEopt with the options of a full basement or slab foundation with garage, and simulated in the various climates to gather garage, basement, attic, and interior temperatures with which to simulate the distribution systems. The original trunk and branch layout was used to determine locations and lengths of plumbing needed to reach the fixtures. The layouts were modified for homes with basements in that the plumbing would span beneath the floor and basement while the original garage model had the plumbing routed through the attic. As an example, original line diagram is shown in Figure 2. Diagrams for the other distribution options, as well as a table listing of the differences in distribution options are provided in Appendix B. 


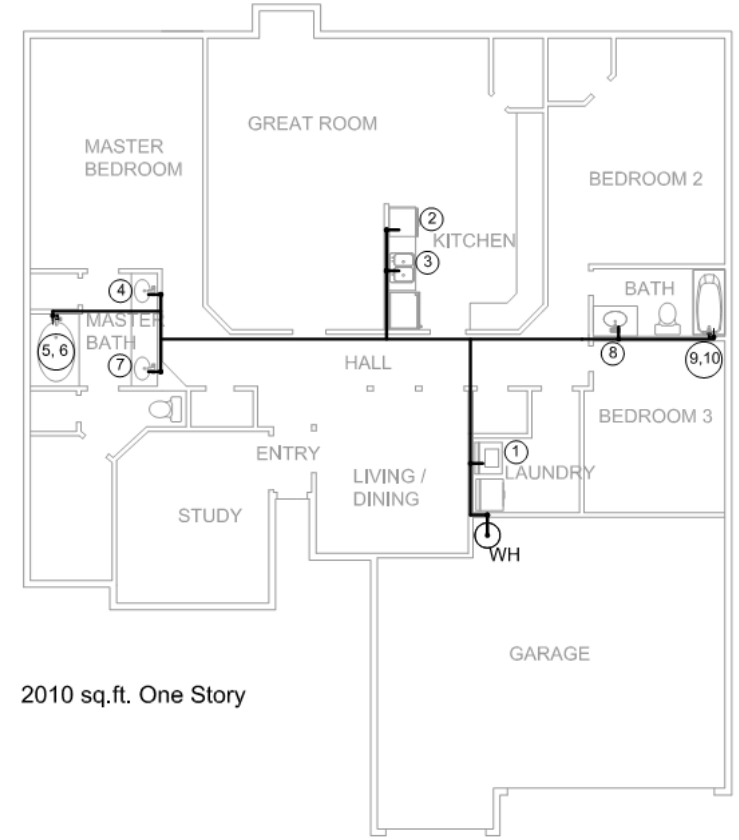

Figure 1. Sample home layout

Source: Backman and Hoeschele 2013

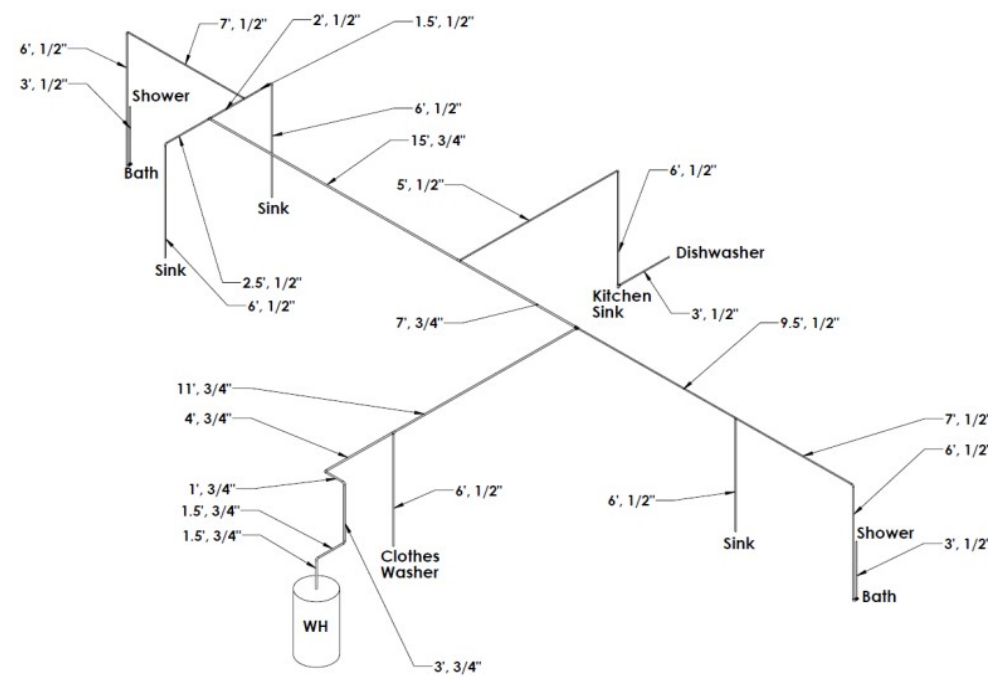

Figure 2. Sample distribution layout

Source: Maguire et al. 2011

In each distribution system evaluated, the plumbing configuration and insulation level were adjusted to represent a best- and worst-case scenario. In trunk and branch systems, the worst case involves a water heater mounted near the far corner of the garage or basement, with a resulting long main trunk feeding the uninsulated distribution piping. The best trunk and branch case layout is a centrally located water heater, a shortened main line, and all pipes insulated to R4.7. 
In home run systems it is assumed from field experience the worst-case scenario involves a 15-ft, 1-in. diameter main line between the water heater and the manifold, with $1 / 2$-in. lines supplying all use points from the manifold. Our experience is that it is typical practice to insulate the 1-in. main line; therefore, in the worst-case ("uninsulated") system the main line is the only insulated pipe. The optimal home run configuration reduces the main line to a significantly reduced length of $3 \mathrm{ft}$ of $3 / 4-i n$. line, and also assumes lines to the sinks and dishwasher are reduced to $3 / 8$ in.

Finally, in hybrid systems, the worst-case scenario involves a 15-ft, 1-in. diameter main line, with $1 / 2$-in. lines to all the use points. The line between the water heater and the first distribution manifold is insulated, while the supply lines to the use points remain uninsulated. In the optimal case, all lines are insulated, runs to sinks and the dishwasher are reduced to $3 / 8$ in. and the main line is both shortened in length and reduced to $3 / 4$ in.

Demand recirculation technology was also modeled because it represents a preferred approach for applications where recirculation is desired. By minimizing the operation of the recirculation pump to only when needed at the start of a draw, recirculation loop heat loss and pumping energy are significantly reduced relative to conventional recirculation strategies. Proponents of the technology suggest that it not only saves water, but energy as well when compared to conventional nonrecirculating strategies. For this evaluation, two demand recirculation plumbing configurations were analyzed. Water heater researcher Gary Klein has conveyed in personal communications that an optimal system requires all use points be less than $15 \mathrm{ft}$ from the recirculation loop. In this "short run-out configuration," the recirculation loop was brought to within $15 \mathrm{ft}$ of pipe from the master bath and bath two showers, ensuring all use points were within range. In the "long run-out configuration," the recirculation loop was shortened (decreased in total length by $32 \mathrm{ft}$ ), extending the furthest shower to $23 \mathrm{ft}$ from the recirculation line.

In total, 124 models were analyzed with the list of parameters evaluated shown in Table 1.

Table 1. Evaluation Parameters

\begin{tabular}{c|c|c}
\hline Parameter & Options & Contingent \\
\hline Occupancy & 2-, 4-person household & \\
\hline Climates & Houston, Denver, Phoenix, Chicago, Atlanta & Typical for climate \\
\hline House Types & Basement, garage & \\
Distribution Types & Trunk and branch, home run, hybrid & \\
Water Heater \\
Location and \\
$\begin{array}{c}\text { Plumbing Practices } \\
\text { Insulation }\end{array}$ & $\begin{array}{c}\text { Wasteful case with water heater nearest exterior } \\
\text { wall, }\end{array}$ & \\
Recirculation & Compact case with central water heater & \\
\hline
\end{tabular}

\subsection{Building America Domestic Hot Water Event Schedule Generator}

The models were evaluated using draw schedules supplied by the DHWESG shown in Figure 3. The generator was developed from two studies conducted by Aquacraft (Aquacraft 2008; Mayer and DeOreo 1999). One study gave insight into discrete water draw events by monitoring the 
disaggregated uses in 20 homes. The other study involved 1,200 homes in which only total water consumption was monitored. The DHWESG includes assumptions for structural and behavioral waste in the draw events, driven by a fixed useful hot water set point (e.g., $110^{\circ} \mathrm{F}$ ) for nonappliance loads. As the TRNSYS model evaluates distribution system contribution to waste, it was necessary to reduce the nonappliance loads in the draw schedule so that waste wouldn't be accounted for twice. As some draws were only a single time-step, the flow rates were reduced. In the study that validated the distribution system, the water waste was nearly climate independent at $20 \%-22 \%$ of total hot water use. For this evaluation, the sink, shower and bath loads in the generated schedules were reduced by $22 \%$ before being supplied to the model.

\begin{tabular}{|c|c|c|c|c|c|c|c|c|c|c|}
\hline \multicolumn{2}{|c|}{ DHW Event Schedule Generator (Updated 03/07/13) } & \multirow{2}{*}{$\begin{array}{c}\text { Stant Time } \\
1 \text { 1/1 12:20:18 AM }\end{array}$} & $\begin{array}{c}\text { Duration } \\
\text { (sec) }\end{array}$ & Fixture & $\begin{array}{l}\text { Flow Rate } \\
\text { Hot \& Cold } \\
\text { (Bpm) }\end{array}$ & $\begin{array}{l}\text { Flow Rate } \\
\text { Hot Only } \\
\text { (gem) }\end{array}$ & \multirow[t]{2}{*}{$\begin{array}{c}\text { Flow Rate } \\
\text { Cold Only } \\
\text { (gpm) } \\
0.392\end{array}$} & \multirow[t]{2}{*}{\begin{tabular}{|c|}
$\begin{array}{l}\text { Dally Draw } \\
\text { Hot \& Cold } \\
\text { (gal/day) }\end{array}$ \\
92.7 \\
\end{tabular}} & \multirow[t]{2}{*}{$\begin{array}{l}\text { Dally Draw } \\
\text { Hot Only } \\
\text { (gal/day) }\end{array}$} & \multirow[t]{2}{*}{$\begin{array}{l}\text { Daily Draw } \\
\text { Cold Only } \\
\text { (gal/day) }\end{array}$} \\
\hline Number of Bedrooms & 5 & & 6 & $\operatorname{sink} 3$ & 1.753 & 1.361 & & & & \\
\hline DHW Tank Temperature ( $\mathrm{P}$ ) & 125 & 1/1 12:22:12 AM & 12 & Kitchen Sink & 1.695 & 1.316 & 0.379 & & & \\
\hline Temperature of Shower, Sink, and Bath draw & 110 & 1/1 4:17:18 AM & 48 & Kitchen Sink & 1.218 & 0.946 & 0.272 & & & \\
\hline Climate Location (TMY3 Site) & Actlanta-Hartsfleld-|ackson Int, GA & $1 / 17: 00: 30 \mathrm{AM}$ & 96 & Kitchen Sink & 0.991 & 0.769 & 0.222 & & & \\
\hline \multirow{2}{*}{ 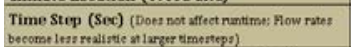 } & 6 & $1 / 17: 45: 30 \mathrm{AM}$ & 144 & $\mathrm{cw}$ & 1.66 & 1.66 & 0 & & & \\
\hline & 6 & 1/18:34:06 AM & 60 & Sink 2 & 0.694 & 0.539 & 0.155 & & & \\
\hline \multirow{3}{*}{ 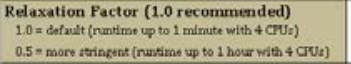 } & \multirow[t]{3}{*}{1.0} & $1 / 18: 44: 36 \mathrm{AM}$ & 54 & Kitchen Sink & 1.378 & 1.07 & 0.308 & & & \\
\hline & & 1/18:46:00 AM & 108 & Sink 4 & 1.095 & 0.851 & 0.244 & & & \\
\hline & & $1 / 10: 47: 54$ AM & 6 & Kitchen Sink & 0.021 & 0.017 & 0.004 & & & \\
\hline \multirow{3}{*}{\multicolumn{2}{|c|}{-5}} & $1 / 18: 49: 48$ AM & 18 & Kitchen Sink & 1.299 & 1.009 & 0.29 & & & \\
\hline & & 1/19:44:24 AM & 66 & $\mathrm{CW}$ & 2.843 & 2.843 & 0 & & & \\
\hline & & $1 / 110: 22: 00 \mathrm{AM}$ & 36 & Sink 4 & 1.386 & 1.076 & 0.31 & & & \\
\hline \multirow{5}{*}{\multicolumn{2}{|c|}{ 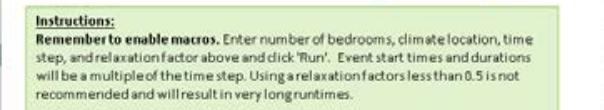 }} & 1/1 10:23:54 AM & 78 & Kitchen Sink & 1.411 & 1.096 & 0.315 & & & \\
\hline & & $1 / 110: 25: 48 \mathrm{AM}$ & 36 & Sink 2 & 0.284 & 0.22 & 0.064 & & & \\
\hline & & $1 / 110: 27: 48 \mathrm{AM}$ & 6 & Kitchen Sink & 0.76 & 0.591 & 0.169 & & & \\
\hline & & $1 / 110: 29.42 \mathrm{AM}$ & 30 & Kitchen Sink & 0.775 & 0.602 & 0.173 & & & \\
\hline & & 1/1 10:58:42 AM & 72 & $\mathrm{CW}$ & 1.753 & 1.753 & 0 & & & \\
\hline \multirow{5}{*}{\multicolumn{2}{|c|}{ 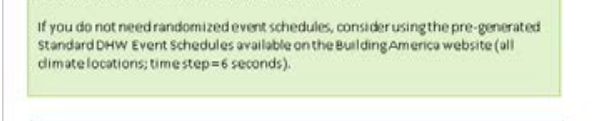 }} & 1/1 11:39:12 AM & 42 & Kitchen Sink & 0.381 & 0.296 & 0.085 & & & \\
\hline & & $1 / 111: 40: 48 \mathrm{AM}$ & 30 & $\operatorname{sink} 3$ & 1.877 & 1.458 & 0.419 & & & \\
\hline & & $1 / 111: 42.4 B$ AM & 30 & Kitchen Sink & 1.292 & 1.003 & 0.289 & & & \\
\hline & & $1 / 111: 44: 42$ AM & 48 & Kitchen Sink & 0.82 & 0.637 & 0.183 & & & \\
\hline & & $1 / 11: 44: 42 \mathrm{PM}$ & 30 & Kitchen Sink & 0.676 & 0.525 & 0.151 & & & \\
\hline \multirow{7}{*}{\multicolumn{2}{|c|}{ 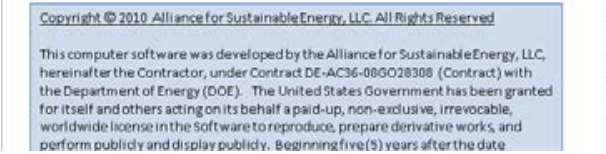 }} & $1 / 11: 46: 36 \mathrm{PM}$ & 12 & Kitchen Sink & 1.699 & 1.319 & 0.38 & & & \\
\hline & & $1 / 12: 55: 24$ PM & 42 & Sink 3 & 1.062 & 0.825 & 0.237 & & & \\
\hline & & 1/1 $3: 37: 24 \mathrm{PM}$ & 6 & Kitchen Sink & 0.006 & 0.005 & 0.001 & & & \\
\hline & & $1 / 13: 39: 54 \mathrm{PM}$ & 336 & Shower 1 & 4.215 & 3.273 & 0.942 & & & \\
\hline & & 1/14:10:30 PM & 360 & Shower 1 & 2.922 & 2.269 & 0.653 & & & \\
\hline & & 1/1 4:30:48 PM & 6 & Kitchen Sink & 0.573 & 0.445 & 0.128 & & & \\
\hline & & 1/1 4:32:42 PM & 30 & Kitchen Sink & 1.101 & 0.055 & 0.246 & & & \\
\hline
\end{tabular}

Figure 3. DHWESG output

Source: NREL DHWESG

The DHWESG output format consists of a date and time stamp, draw event duration and discrete flow rates. As the TRNSYS model requires input files to be at a discrete time step, a python script was developed to take a fixed, user-supplied time step and generate individual files for cold and hot water draws by fixture. The TRNSYS model simulates at a 6-second time step as the minimum draw duration specified by the DHWESG, therefore the draw schedule files contain a full year of 6-second records.

\subsection{TRNSYS Distribution Model Description}

TRNSYS is a widely adopted simulation tool that is flexible in using any combination of models, including user-specified models, to analyze equipment and building system performance. HWSIM is a narrowly focused simulation tool for analyzing DHW systems and is only newly enhanced with high fidelity water heating and control models.

Where HWSIM has its advantage is that distribution systems may be quickly laid out and analyzed in a matter of minutes with simple water heater system models. HWSIM comes integrated with several recirculation control options and individual use points may be easily and individually configured to operate either as a tub draw (fixed final energy condition), minimum required supply temperature, or fixed volume flow (appliances). HWSIM is also publicly 
available and the results are easily generated in either discrete, tabular, or refined summary reports. HWSIM lacks the ability to model simultaneous (i.e., overlapping) draws, and in order to expedite simulation speeds with high fidelity water heating models, the input draw schedules were reduced to three representative seasonal days (winter, summer, and spring/fall).

Where TRNSYS has its advantage is with the flexibility of analyzing a variation of conditions, including buried pipes, concurrent draw events, and a full year of hourly temperatures and draw schedules. TRNSYS takes significantly more effort to develop and input a model, with large systems consisting of individual pipe elements that require multiple conditions and inputs. In addition, each individual branch requires a discrete control element to direct the flow to the corresponding use point. Outputs are manually formatted and reported in user-specified delimited files, and full annual simulations at a 6-second time step take approximately 5 hours to complete. TRNSYS is not capable of easily adjusted parametric evaluations, therefore an individual model and input file is needed to evaluate each option, climate, and draw schedule.

While HWSIM has some benefits, TRNSYS is much more widely used, and in an effort to build upon our prior validation work, it was decided to use TRNSYS to evaluate the various distribution systems. The validated model shown in Figure 4 consists of an electric storage water heater (Type 534 set at $120^{\circ} \mathrm{F}$ ), ${ }^{2}$ individual piping elements (Type 604a), diverters (Type 11), Typical Meteorological Year 3 weather file and individual file readers for hourly zone (attic, basement, garage, indoor) temperatures generated by BEopt and the six second draw schedule file. The diverters are controlled by inline calculators that determine the fraction of flow through each branch from the draw schedule. In each distribution system evaluated, the calculators had to be rewritten as needed to accommodate the change in routing. The original validated model was driven by the combined hot and cold flow rates generated by the DHWESG, and controlled output temperature with a series of valves to maintain non-appliance loads at the desired temperature. The model's useful energy delivered varied across climates as the useful hot water volumes correlated with pipe heat loss. This makes it difficult to accurately evaluate the impact of climate and plumbing configurations on distribution loss. The validated model also did not evaluate demand recirculation as there is no existing TRNSYS model available. In order to accurately model useful energy delivered and recirculation systems, component models needed to be written to control the water supply.

\footnotetext{
${ }^{2}$ Nationally gas water heating is slightly more common that electric water heating. Because the focus of the study was on the distribution system, we decided not to make water heater type an added parametric case. The recovery load (energy leaving the water heater) would be similar in either case.
} 


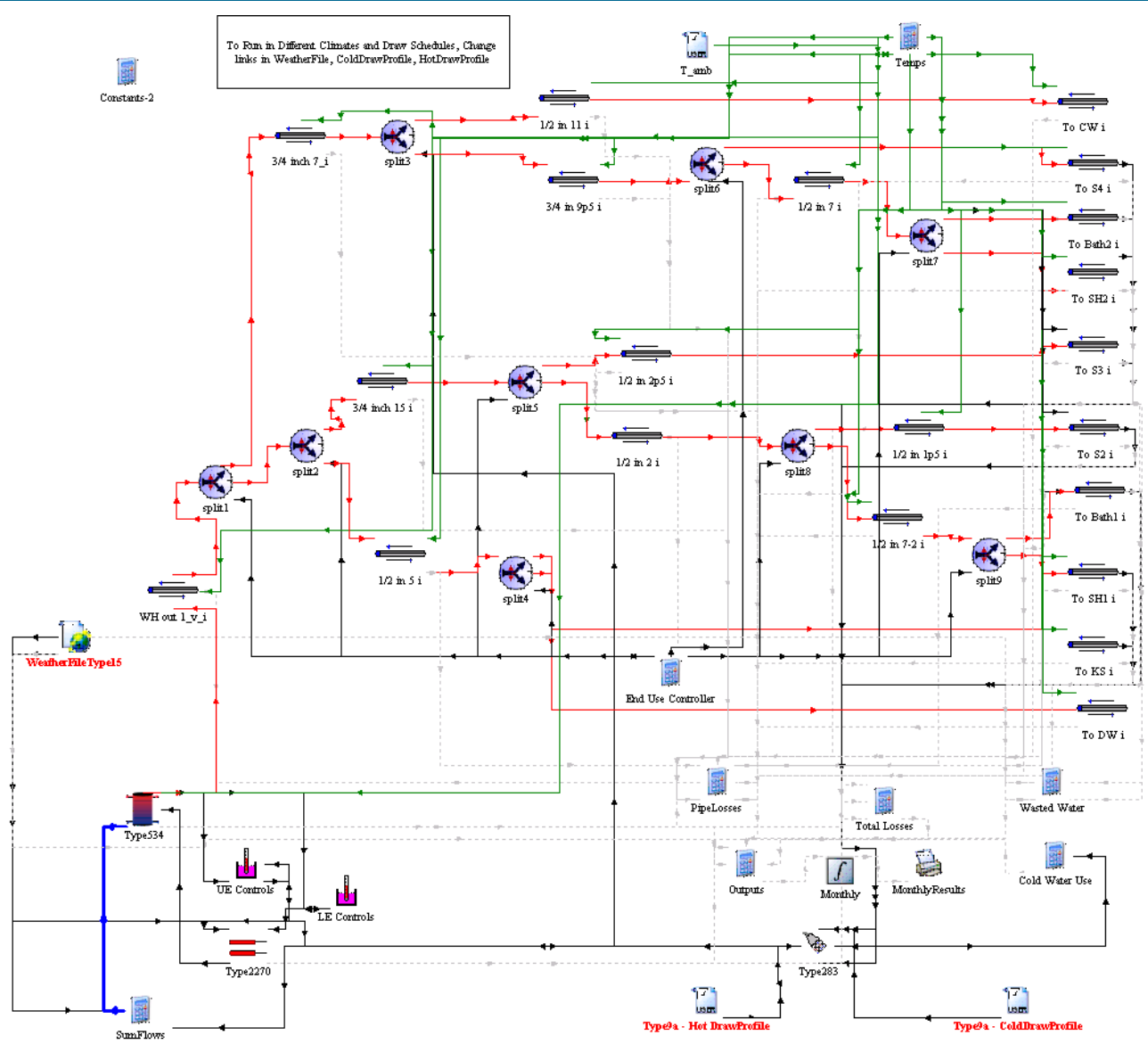

Figure 4. Representation of TRNSYS model configuration

\subsection{Delivered Hot Water Control Model}

The draw schedule supplied from the DHWESG takes into account non-appliance mixed flow temperature setting and a basic assumption for water waste. The flow rates are fixed throughout the draw event and the prior TRNSYS model used the mixed flow schedule to drive the simulation. A component model was created in FORTRAN and compiled for use in TRNSYS that takes into account the separate hot and cold water schedules and use point temperatures to control the hot and cold water flows. The control model observes the fixture temperature and throttles the hot and cold flow rates to deliver specified tempered water to the use point. The draw schedule is considered to be a schedule of desired useful hot water volumes, therefore insufficiently hot flows are accumulated as water waste and the draw is extended until the desired volume of useful hot water is reached.

\subsection{Demand Recirculation Model}

In addition to the delivered hot water control model, a demand recirculation model required development. The demand recirculation control model makes use of the hot water control model to meet the desired fixture useful hot water volume and applies an additional control delay for recirculation time. The model takes a user-specified control location in the distribution system in which to monitor temperature and outputs a binary signal for pump runtime, which then could be used to estimate pumping energy and drive recirculation flow rates. Research is still being conducted on behavioral use of demand recirculation systems. In most models (including 
HWSIM), it is assumed that demand recirculation is initiated prior to each draw, and once the control point temperature is reached, the pump shuts off and the draw commences. For this demand control model, a user-specified fixed time delay is applied before a draw. If the control point temperature is not yet reached, the pump continues to operate along with the draw until the control point temperature is reached. The flows are modulated to deliver the desired useful hot water volume and hot water that is insufficiently hotis accumulated as waste. The control, as modeled, represents optimized demand recirculation control, both in terms of perfect initiation for all draws, and immediate subsequent hot water use. An alternative occupancy sensor based control strategy would demonstrate degraded performance as it is prone to prime the recirculation loop at times when hot water draws do not necessarily follow the pump activation. A prior single home study that Davis Energy Group completed under the CARB team in 2003, suggested that $70 \%$ of occupancy sensor pump signals were not followed by a hot water use event (DEG 2003). 


\section{Results}

In conducting the evaluations a set of parameters were varied to determine the sensitivity of the results. TRNSYS is not capable of Monte Carlo simulations, and each variation requires a separate model, resulting in the 124 models prescribed. Simulating the model over a full year at a 6-second time step, the average runtimes were 5 hours each, excessively long for direct integration with annual whole-building simulations. By analyzing the sensitivity of the outputs, assumptions may be made that will integrate better into whole-building simulations. The key outputs are distribution losses, water consumption, and water waste. The parameters evaluated that influence these results are occupancy, climate, building types, distribution types, typical plumbing, and insulation practices. With six parameters varied, it is necessary to hold some parameters constant or averaged, to inspect the independent influence on results. In the results expressed in the following section, we begin by looking at the system results averaged over climate and occupancy. Distribution losses, water heater energy consumption, hot water use, and waste are examined separately to determine significance of climate, plumbing practice, and insulation influence. Further inspection can be made with additional parameters varied, such as water heating type and different recirculation strategies, but are beyond scope of this analysis and are suggested for further research.

In all nonrecirculation distribution options, water heater energy consumption and hot water waste are correlated. A decrease in water heater energy consumption follows a reduction in wasted water; therefore, improving insulation and reducing the piping length and/or pipe diameter have equal benefits for energy and water waste. In recirculation systems, water heater energy consumption and wasted hot water are independent, and often have an inverse effect. Averaging across climates, Figure 5 and Figure 6 show the ranking of various distribution options by average annual energy consumption for the two- and four-person households, respectively, with the most energy efficient configuration shown at the left-hand side. In all climates this rank was the same, with the insulated, central heater, trunk and branch system using the least amount of energy and the short-run recirculation system wasting the least amount of hot water. Highlighted in yellow are uninsulated trunk and branch systems that are typical plumbing practices in existing single-family homes and reference as the base case. 


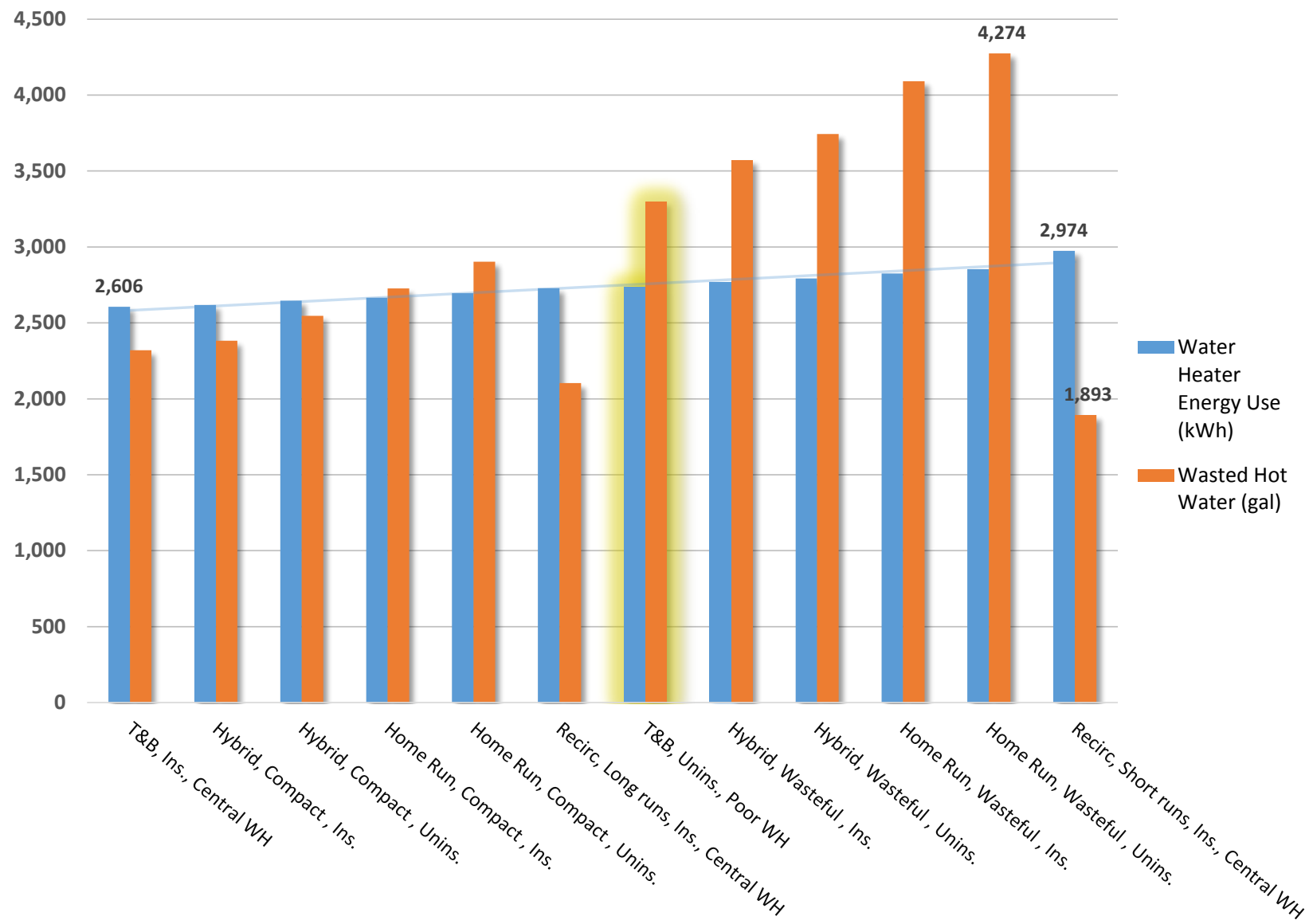

Figure 5. System ranking by annual water heater energy use and waste (2 person)

For a two-person household, the greatest projected reduction in annual water heater energy use is $128 \mathrm{kWh}$ from the base case, which is achieved by insulating and locating the water heater centrally to the distribution system. For the same case, the water waste improvement is 978 gal/year (30\% reduction). For short run recirculation systems, a reduction in hot water waste of 1,405 gal (36\% reduction) comes at a cost of $240 \mathrm{kWh}$ annually. By lengthening the run-outs and shortening the recirculation loop, there is an improvement in energy savings $(6 \mathrm{kWh} /$ year $)$ and wasted hot water (1,194 gal/year) and over the base case, however the site energy savings are not enough to cover the cost of the recirculation pump. ${ }^{3}$

\footnotetext{
${ }^{3}$ Factoring in the embedded energy in municipal water nationally (Copeland 2014), the energy savings with the reduction in water waste is at best an additional $4.8 \mathrm{kWh} / \mathrm{year}$. While the energy varies significantly nationally, even in southern California (Klein 2005), the energy savings are only $17.4 \mathrm{kWh} /$ year. Factoring in the embedded water use in electricity generation (Wilson et al. 2012), the most energy-efficient option saves an additional 5,325 gal/year.
} 


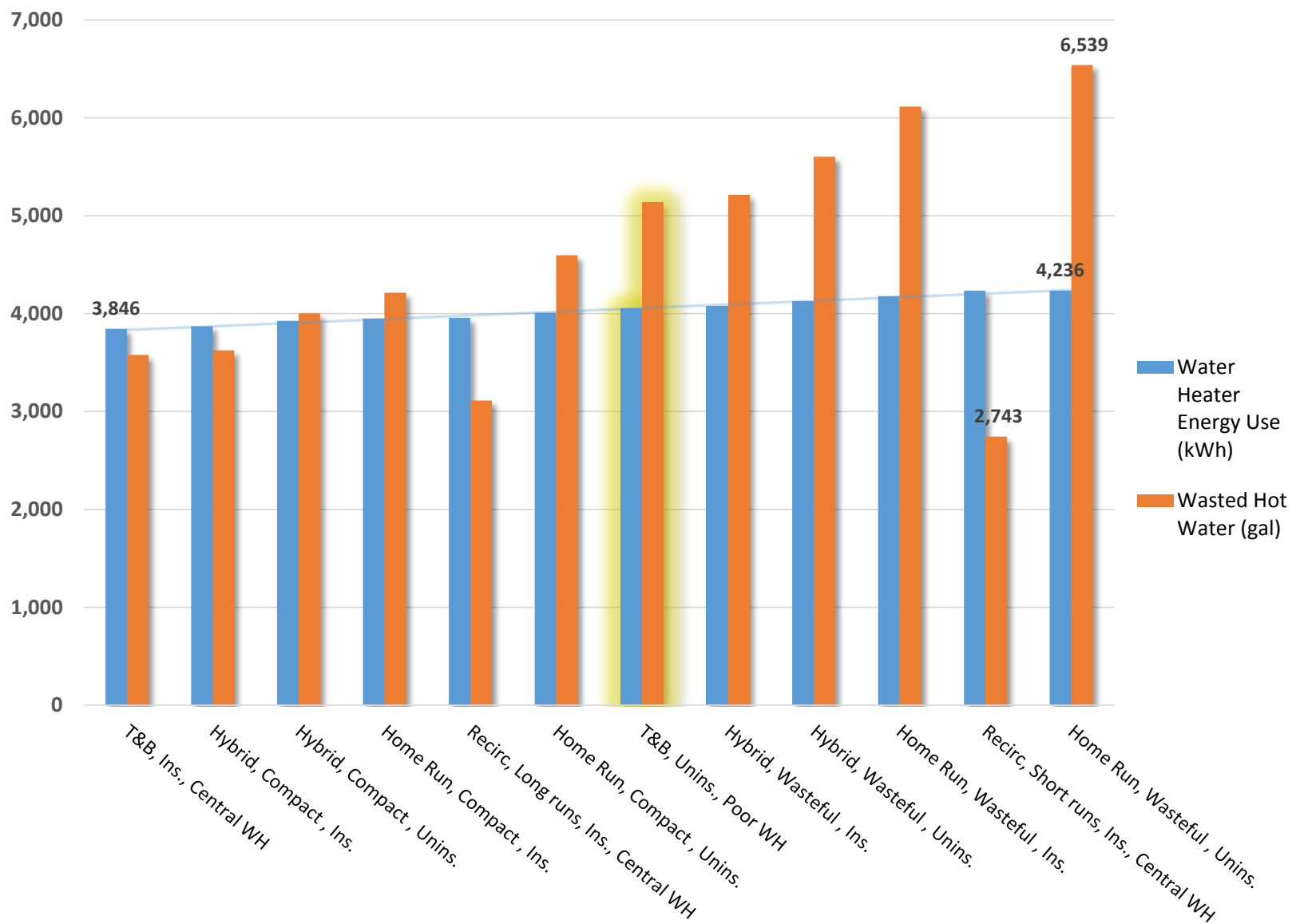

Figure 6. System ranking by annual water heater energy use and waste (4 person)

For a four-person household, the greatest projected reduction in annual water heater energy use is $203 \mathrm{kWh}$ from the base case. For the same case (insulated trunk and branch with central water heater) the water waste improvement is $1,555 \mathrm{gal} /$ year. At this higher hot water consumption level, home run systems are projected to be the worst energy performer; however, only by a small margin $(2 \mathrm{kWh}$ /year) from the short run recirculation system. Again, for short run recirculation systems, a reduction in hot water waste of 2,391 gal comes at a cost of $185 \mathrm{kWh}$ annually. Shortening the recirculation loop and lengthening the run-outs save $93 \mathrm{kWh} /$ year and 2,021 gal/year; however, the compact hybrid and trunk and branch systems provide additional energy savings.

\subsection{Distribution Losses}

Distribution losses are defined as both pipe losses during the draw and the wasted energy associated with wasted hot water. The latter term includes behavioral effects that are not easily modeled or quantified. Table 2 shows the fraction of total projected water heater energy use that is lost through the distribution system as determined for the differing climates. From the draw schedules generated, it can be expected that for any system, the distribution losses represent $13 \%-29 \%$ of water heater energy use. Lower loads in more efficient distribution systems result in the lower distribution loss fraction, while higher loads in less efficient systems result in higher distribution loss fraction. Breaking out the distribution types shows only a slightly narrower 
range of distribution losses, indicating that other factors, including insulation and pipe lengths, have a larger impact on distribution losses than climate and type. It is important to note that demand recirculation has higher distribution losses due to the increase in the volume of water flowing through the (larger diameter) recirculation plumbing. Cold climates have slightly better recirculation system performance, due in part to the location of the distribution system being between the basement and the subfloors, whereas the other climates piping is routed through the attic space.

Table 2. Range of Distribution Losses as a Percentage of Total Water Heater Annual Energy Use

\begin{tabular}{c|c|c|c|c}
\hline Climate & $\begin{array}{c}\text { Trunk and } \\
\text { Branch }\end{array}$ & Home Run & Hybrid & Recirculation \\
\hline Hot-Humid (Houston) & $13 \%-20 \%$ & $15 \%-23 \%$ & $13 \%-20 \%$ & $20 \%-29 \%$ \\
\hline Cold (Denver) & $14 \%-20 \%$ & $16 \%-23 \%$ & $13 \%-20 \%$ & $18 \%-26 \%$ \\
\hline Hot-Dry (Phoenix) & $14 \%-19 \%$ & $15 \%-23 \%$ & $13 \%-20 \%$ & $19 \%-28 \%$ \\
\hline Cold (Chicago) & $14 \%-20 \%$ & $15 \%-23 \%$ & $13 \%-20 \%$ & $18 \%-26 \%$ \\
\hline Mixed-Humid (Atlanta) & $14 \%-20 \%$ & $15 \%-23 \%$ & $14 \%-21 \%$ & $19 \%-28 \%$ \\
\hline
\end{tabular}

Averaging across the climates, the various cases were ranked again in terms of the fraction of annual energy consumption represented by the distribution system. The base case of uninsulated trunk and branch is highlighted in yellow for reference. Insulated hybrid systems, compact home run, and the combination of insulating and centrally locating the water heater on a trunk and branch system all have less distribution losses than the base case. The short run recirculation system has the highest distribution losses due to the large recirculation run. All recirculation systems have higher distribution losses than the base case for this reason. The hybrid and home run systems marked as wasteful have an extended length of pipe between the water heater and the manifold, as is typically seen with PEX systems. 


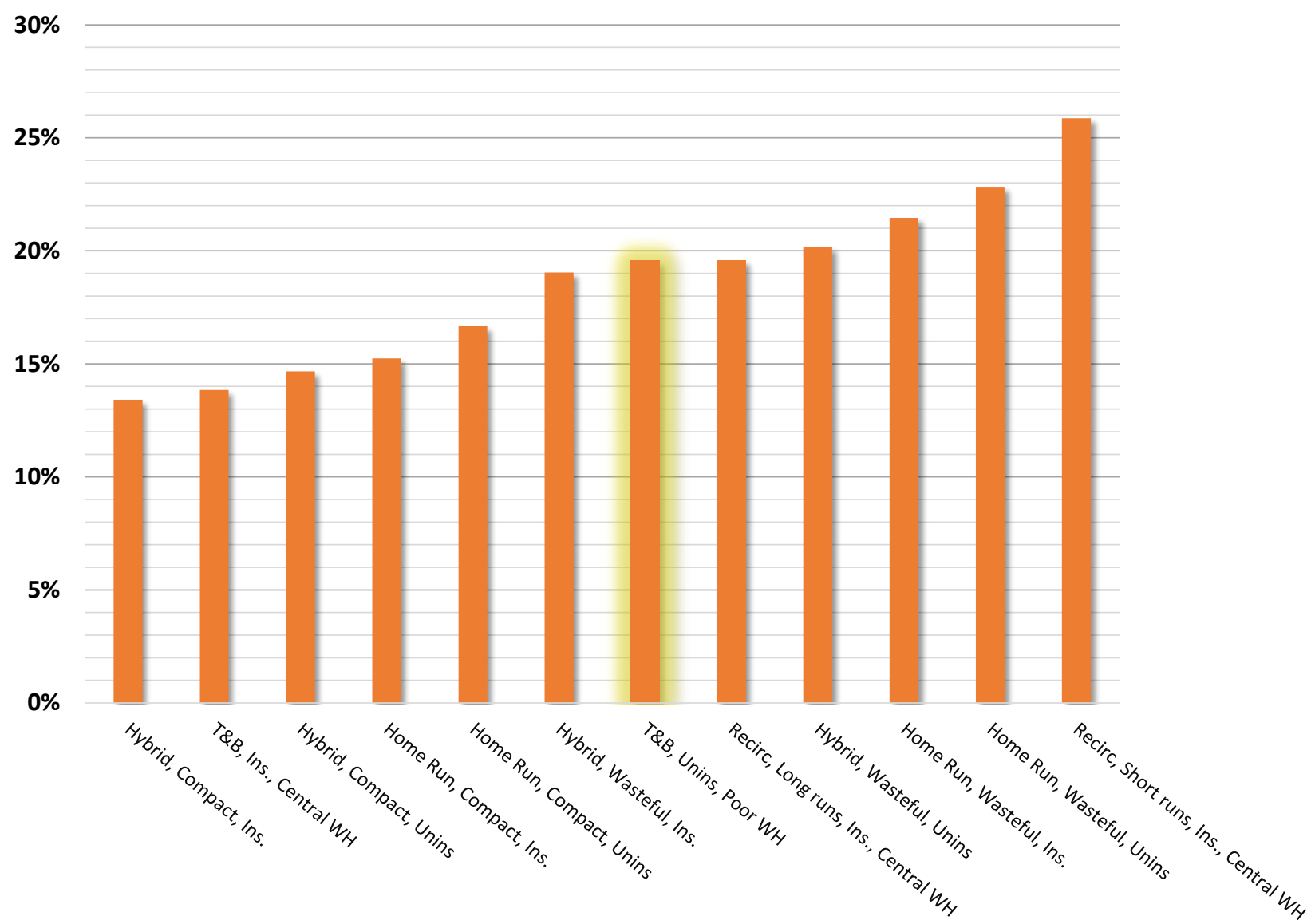

Figure 7. System ranking by percent distribution loss of total water heater energy use

Both piping lengths and pipe diameter have strong influence on distribution losses. Even with recirculation systems, the total enclosed volume of water between the water heater and the use point impacts the percentage of energy use that is lost to the distribution system. In all the cases evaluated, for every 10 gal of water volume reduced by compact plumbing practices, there is a reduction of $2.6 \%-4 \%$ of water heater energy losses. For instance in home run systems, by reducing the main pipe between the water heater and the manifold, and reducing the pipe diameter of sink and dishwasher runs to $3 / 8$ in., 24 gallons of enclosed water and $6 \%$ of water heater energy are saved.

Likewise, insulation has an impact on pipe heat loss. In Figure 8, distribution losses as a fraction of water heating energy use are shown for the various plumbing types with and without insulation. Recirculation systems show the largest benefit from insulation, due to the larger pipe diameters and lengths (i.e., enclosed volume). The cost effectiveness of pipe insulation, especially in piping $<3 / 4$ in. diameter, is diluted by the reduced available "savings per foot," and the reduced transit time of hot water in smaller pipes. 


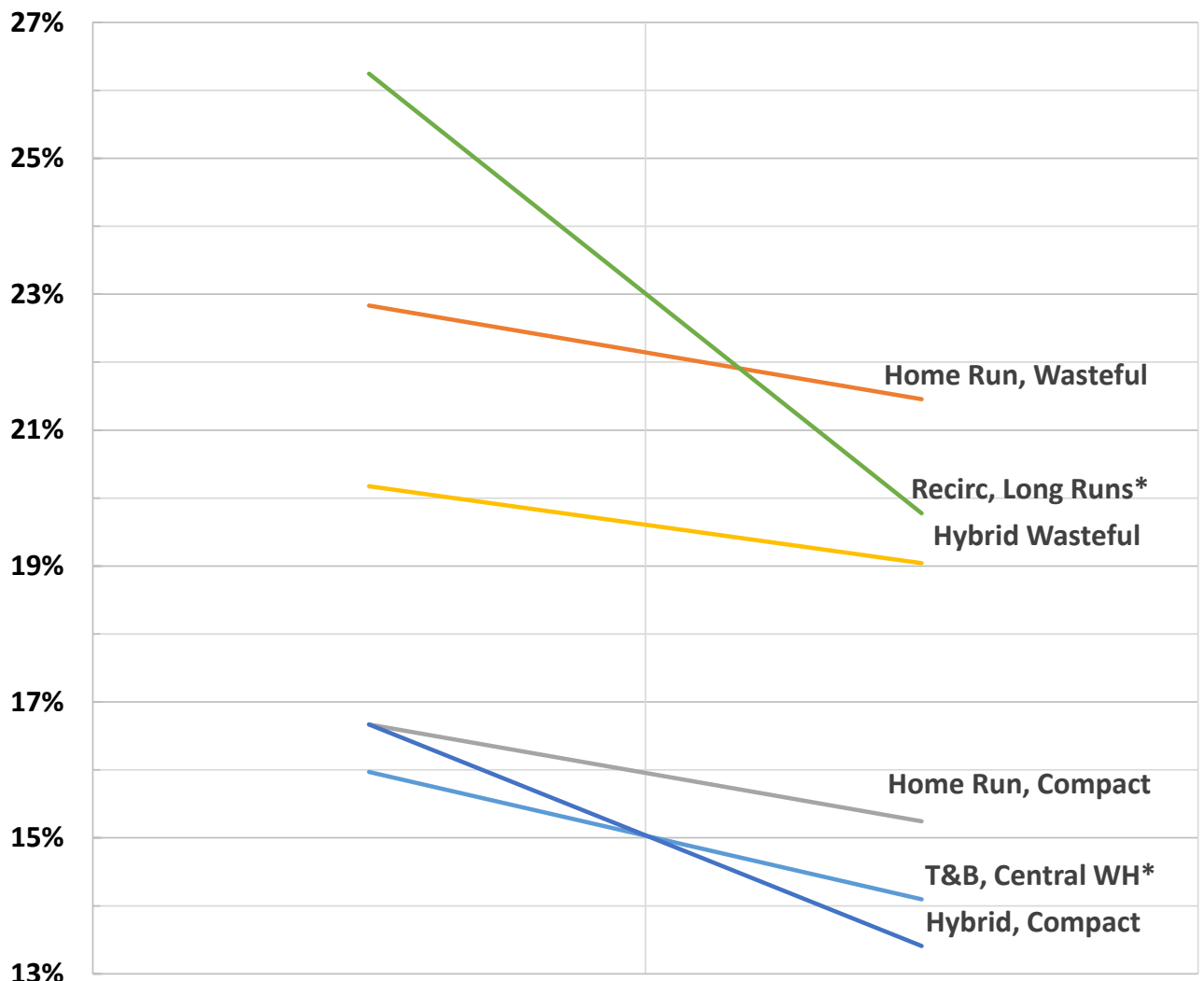

Uninsulated

Insulated

Figure 8. Insulation impact on distribution loss percent of annual water heater energy use

* These are shown for Atlanta only. ${ }^{4}$

\subsection{Projected Energy and Water Savings}

The energy and water savings of each distribution type and option compared with the base case are presented in Table 3. Uninsulated trunk and branch systems are typical plumbing practices, while home run and hybrid systems are gaining traction. Recirculation loops are often proposed for larger houses and plumbing systems with long distances between use points. Uninsulated trunk and branch systems are projected to consume $1,190 \mathrm{kWh}$ per person per year, with distribution losses accounting for approximately $20 \%$ of the water heating energy. The water waste accounts for approximately $18 \%$ of the total water use. By simply relocating the water heater to a central location and insulating the pipes, the enhanced system saves nearly $5 \%$ of the water heater energy consumed in the base case, with the next best option being an insulated compact hybrid system. Both the insulated compact trunk and branch and hybrid systems save more than $30 \%$ in distribution losses.

Plumbing practices such as extending runs to avoid the use of elbows and larger than required supply lines should be avoided as they both increase energy consumption and water consumption.

\footnotetext{
${ }^{4}$ The uninsulated case was run in one sample climate to reduce the number of parametric runs. The comparison to insulated is shown for Atlanta only.
} 
In nonrecirculation systems, the distribution loss savings of the improved systems are slightly higher than the water heater energy savings. This is due to the fact that some of the draws with the improved systems are satisfied by the enclosed water in the distribution system that is barely above an acceptable minimum use condition. The lower delivery temperatures require an increased hot water flow rate needed to satisfy the draw, until the line is flushed with hot water from the water heater. In recirculation systems, the inverse is true, the higher temperatures from the nearby recirculation loop mean more hot water is delivered than is wasted.

Table 3. Distribution Systems Savings in Energy, Distribution Loss, Water Use, and Water Waste Relative to Base Case, Averaged Over Climates and Occupancy Levels

\begin{tabular}{|c|c|c|c|c|}
\hline Distribution Type & $\begin{array}{c}\text { Annual } \\
\text { Water } \\
\text { Heater Use } \\
\text { (kWh/ } \\
\text { person) }\end{array}$ & $\begin{array}{c}\text { Distribution } \\
\text { Losses } \\
\text { (kWh/ } \\
\text { person) }\end{array}$ & $\begin{array}{c}\text { Total Hot } \\
\text { Water Use } \\
\text { (gal/ } \\
\text { person-day) }\end{array}$ & $\begin{array}{l}\text { Wasted Hot } \\
\text { Water } \\
\text { (gal/ } \\
\text { person-day) }\end{array}$ \\
\hline $\begin{array}{c}\text { Base Case: Trunk and Branch, } \\
\text { Uninsulated, Typical WH } \\
\text { Location }\end{array}$ & $\underline{1,190}$ & $\underline{233}$ & $\underline{22.7}$ & $\underline{4.0}$ \\
\hline $\begin{array}{c}\text { Trunk and Branch, Insulated, } \\
\text { Central WH Location }\end{array}$ & $4.8 \%$ & $32.7 \%$ & $5.5 \%$ & $29.9 \%$ \\
\hline $\begin{array}{l}\text { Home Run, Wasteful Plumbing, } \\
\text { Uninsulated }\end{array}$ & $(4.5 \%)$ & $(21.9 \%)$ & $(4.9 \%)$ & $(28.6 \%)$ \\
\hline $\begin{array}{c}\text { Home Run, Wasteful Plumbing, } \\
\text { Insulated }\end{array}$ & $(3.3 \%)$ & $(13.2 \%)$ & $(3.5 \%)$ & $(21.9 \%)$ \\
\hline $\begin{array}{c}\text { Home Run, Compact Plumbing, } \\
\text { Uninsulated }\end{array}$ & $1.2 \%$ & $15.9 \%$ & $1.6 \%$ & $11.3 \%$ \\
\hline $\begin{array}{c}\text { Home Run, Compact Plumbing, } \\
\text { Insulated }\end{array}$ & $2.5 \%$ & $24.1 \%$ & $3.0 \%$ & $17.6 \%$ \\
\hline $\begin{array}{c}\text { Hybrid, Wasteful Plumbing, } \\
\text { Uninsulated }\end{array}$ & $(2.1 \%)$ & $(5.2 \%)$ & $(2.2 \%)$ & $(11.6 \%)$ \\
\hline $\begin{array}{c}\text { Hybrid, Wasteful Plumbing, } \\
\text { Insulated }\end{array}$ & $(1.0 \%)$ & $1.8 \%$ & $(0.9 \%)$ & $(5.3 \%)$ \\
\hline $\begin{array}{l}\text { Hybrid, Compact Plumbing, } \\
\text { Uninsulated }\end{array}$ & $3.1 \%$ & $27.4 \%$ & $3.6 \%$ & $22.5 \%$ \\
\hline $\begin{array}{c}\text { Hybrid, Compact Plumbing, } \\
\text { Insulated }\end{array}$ & $4.3 \%$ & $34.4 \%$ & $5.0 \%$ & $28.5 \%$ \\
\hline $\begin{array}{l}\text { Recirculation Loop, Long Run- } \\
\text { outs, Insulated, Central WH } \\
\text { Location }\end{array}$ & $1.1 \%$ & $1.1 \%$ & $10.0 \%$ & $37.6 \%$ \\
\hline $\begin{array}{c}\text { Recirculation Loop, Short Run- } \\
\text { outs, Insulated, Central WH } \\
\text { Location }\end{array}$ & $(7.0 \%)$ & $(41.4 \%)$ & $10.4 \%$ & $44.3 \%$ \\
\hline
\end{tabular}

Recirculation systems are designed to reduce water waste by shortening the length between available hot water and the use point, and do so effectively. Demand recirculation systems offer the added benefit of minimizing pump runtimes and therefore reducing losses relative to 
continually operating recirculation systems. They do experience heat loss during flow, as the energy input needed to bring the loop up to temperature at the start of subsequent pump cycles. The latter can be significant based on the size of the loop and hot water usage patterns, which will dictate how many heat up/cool down cycles exist during a day. A balance exists between getting hot water quickly to all use points (and also minimizing water waste) and the energy penalty associated with a larger recirculation loop. There is a point at which the loop length and water savings can be maximized, but it appears to be in systems with shorter recirculation loops and longer run-outs. Simply the reduction in distribution losses must balance out with the recirculation losses to maximize energy savings. Demand recirculation systems are not projected to provide energy savings relative to an already centrally located water heater with insulated lines for trunk and branch systems. Even by extending the run-outs and shortening the recirculation loop there are marginal water heater energy savings with demand recirculation.

In writing an additional TRNSYS control model that performs a wait for useful hot water and extending the draw so the entire volume of water is satisfied, the useful energy delivered is fairly consistent across distribution systems. In order to compare the various distribution system losses, the distribution loss is expressed as a fraction of useful energy delivered, providing a normalized view of the losses. In Figure 9, the distribution losses are compared for each type across each climate. The base case for each type is the uninsulated, distantly located water heater and wasteful plumbing practice, while the improved system is the compilation of these measures. The improved recirculation system is the system with the short run-outs and long recirculation loop, as suggested. In terms of distribution loss, they do not add any improvement over the smaller recirculation loop. In all climates, the improved hybrid system shows the least amount of distribution loss.

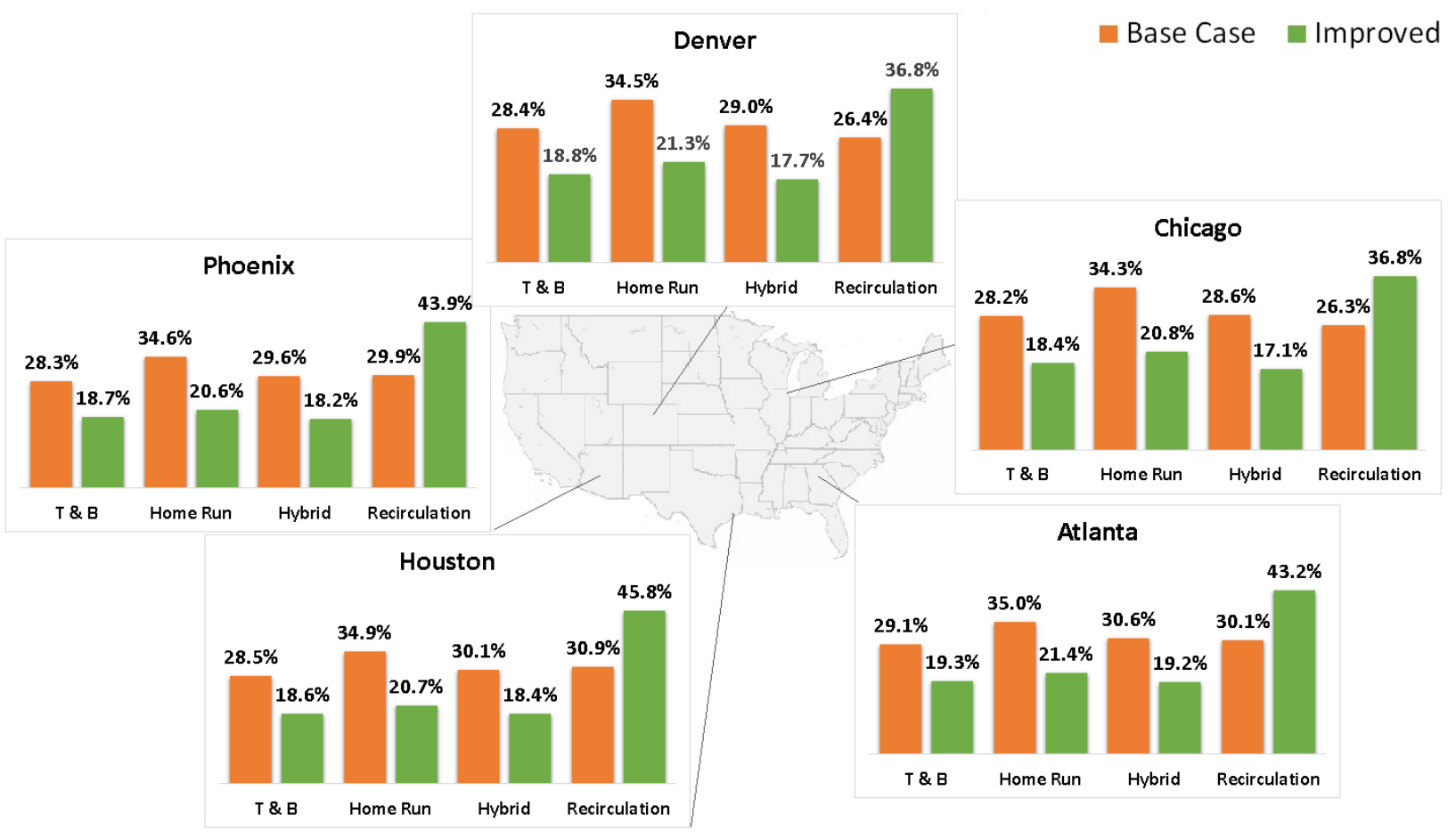

Figure 9. Variation in distribution loss percent of useful energy delivered by climate and installation quality 


\subsection{Water Use and Waste}

The average daily hot water use (combined useful and waste) is presented in Figure 10.

Recirculation systems require the least amount of delivered hot water to satisfy the load, with very little improvement with the short run-out configuration. Cold climates typically use more hot water per day than warmer climates (due primarily to mixing with colder water), as well as seeing a larger variation in water use by distribution configuration. Home run systems consume the most amount of water, yet by improving the plumbing configuration and insulation they make the most improvement in water usage relative to the base home run systems. In all climates, the recirculation systems consume the least amount of water, followed by the improved trunk and branch systems.

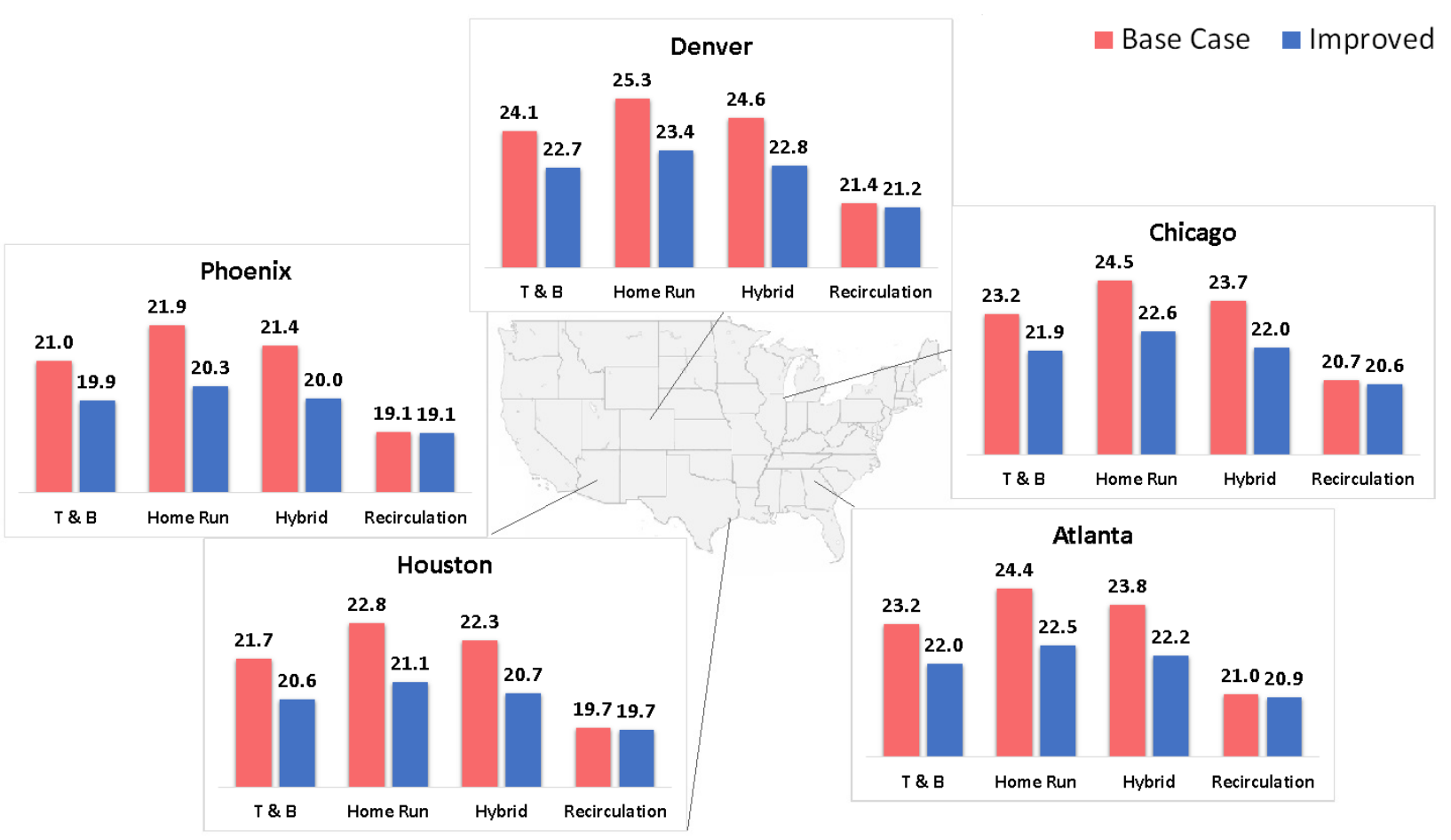

Figure 10. Hot water use (per person, per day) by climate and distribution type

To normalize water waste across the different distribution types, waste is expressed as a fraction of useful hot water delivered, which remains consistent among all cases. In Figure 11, the water waste is compared for the uninsulated wasteful plumbing (base case) and improved systems for each distribution type (green). Again, the recirculation systems show the least water waste, $12 \%-15 \%$. The base case home run system double the water waste, and even improved home run systems waste more water than improved trunk and branch systems. In cold climates, water waste can be as much as $30 \%$ of the total water delivered, $5 \%$ higher than the waste in hot-dry climates. 


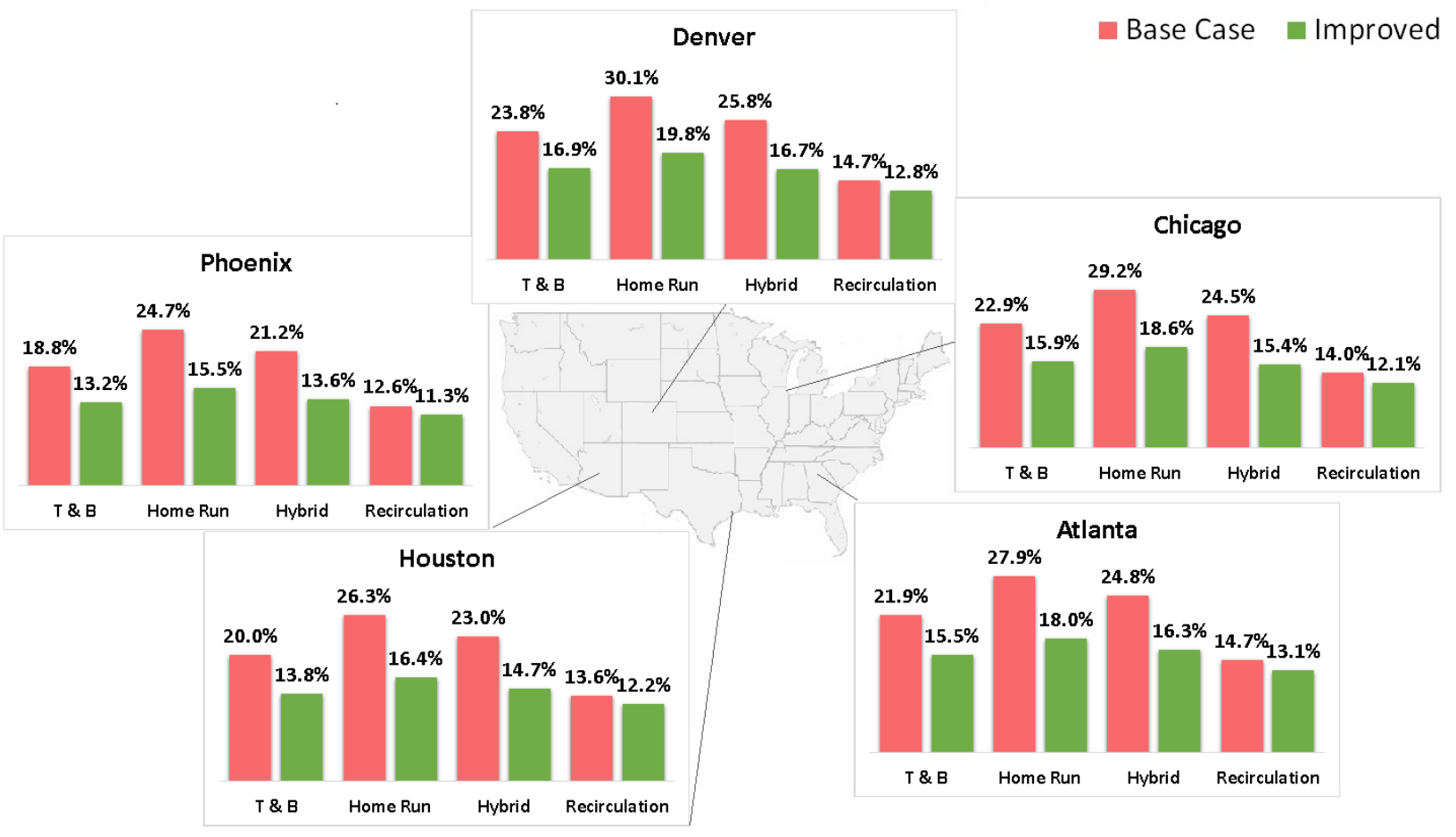

Figure 11. Water waste (as a fraction of useful water delivered) by climate and distribution type 


\section{Conclusions}

The purpose of the project is to provide a deeper understanding of typical energy and water impacts by various distribution system configurations under different load and climate assumptions. While these data give better insight into the sensitivities of distribution performance from several parameters, it is important to highlight that there are wide variances in house architecture, distribution layouts, occupancy levels, and usage patterns. Use point locations do not necessarily dictate distribution layouts and house size is not always correlated with occupancy levels. The results of this research represent a first step in developing a better understanding of the typical parameters to inform a best practices guide to DHW distribution systems. A more thorough Monte Carlo based evaluation strategy is needed to fully characterize the variability of energy and water use. Within the constraints of this study (124 detailed simulations), the authors find that insulated trunk and branch systems with a centrally located water heater provide the most site energy savings (4.8\%), while the short-run recirculation systems provide the most site water savings (10.4\%).

The project has addressed the following research questions:

\section{What is the expected range in distribution losses (as a fraction of water heater recovery load) as a function of distribution system configuration, climate, and hot water usage pattern?}

In general, distribution losses are $13 \%-29 \%$ of the annual electric water heater energy use. Compact insulated systems with low loads have the lowest distribution losses. While climate does influence the total load on the system and the distribution losses, it has little effect on the range of distribution losses between the systems studied. Cold climates experience slightly better recirculation performance compared with warmer climates. Insulated compact hybrid and central trunk and branch systems have the lowest distribution losses. Nearly all "improved" nonrecirculation distribution systems are more energy efficient than the base-case trunk and branch system. Demand recirculation systems with short run-outs consume $7 \%$ more energy than the base trunk and branch system, while the long run-out system provides a marginal $1 \%$ energy savings.

\section{What are the realistic savings that can be realized through measures such as insulating all piping or improving distribution system design?}

For the systems evaluated, insulating all lines saves $1.2 \%(14.3 \mathrm{kWh} /$ person $)$ in water heater energy for the home run and hybrid systems, and nearly $6 \%(71.4 \mathrm{kWh} /$ person $)$ for demand recirculation systems. The fraction of energy savings is due to insulation changes with insulation levels and plumbing lengths. Enclosed volume has a direct influence on energy savings $(2.6 \%-$ $4 \%$ per 10 gal of enclosed pipe volume reduced); therefore, careful consideration to reduce plumbing lengths is important to maximize energy savings. In nonrecirculation systems, improving distribution losses is not directly equal to water heater energy savings, due to the fact that draws are satisfied with thermally "relaxed," or slightly cooled enclosed water, and higher hot water flow rates are initially needed to satisfy the draw, while for recirculation systems, the higher temperatures from the loop result in more water delivered than wasted. In order for recirculation systems to provide savings over the base distribution system, the recirculation losses must be balanced out with savings in distribution losses. 


\section{What are the projected water use/waste implications of the various scenarios simulated?}

The average daily hot water use is lowest in the recirculation systems as waste is minimized by delivering hot water closer to the use points. By insulating and compacting the plumbing on home run systems, water use and waste are the most improved from the base home run system. The insulated trunk and branch system with a centrally located water heater consumes only slightly more water and produces slightly more waste than either of the recirculation systems. The cost to install recirculation pumps and components are typically $\$ 1,000$ and the savings with the long run-out system do not show much more water waste improvement over centrally located water heating systems.

\section{Where are better data needed to improve the characterization of the "hot water system" based on the observed sensitivities in the modeling study?}

While this study evaluated only demand recirculation control strategies, it is expected that losses would only increase with continual, timer, and occupancy sensor-based control. What is not known are behavioral impacts on demand recirculation, how long users wait after pressing the control before using the fixture, and at what locations are they most likely to use the controls. Tankless systems were not evaluated in this study, as the behavioral wastes with tankless systems have not been fully characterized and are needed to understand the impact of water use and waste with the "cold water sandwich" effect. ${ }^{5}$

\subsection{Next Steps}

Modeling hot water distribution systems requires a validated model, accurate characterization of the hot water distribution system, and high-resolution input data related to hot water flows and use point characteristics. Efforts to increase the quality of these data feeding into models are important in improving the understanding of distribution systems and the interactions with the overall hot water system. Improved data are needed to better understand plumbing practices as they exist regionally for both base case system performance and evaluating alternative options.

Further related research is needed to better understand how occupants interact with their hot water system and to what extent behavior impacts system performance projections. The advent of wireless sensing technologies should improve the ability to collect high resolution data at a lower cost. Emerging technologies such as gas tankless, heat pump water heater, and other new technologies will likely influence behaviors to some degree. Theoretically, behavioral assumptions could then be implemented as another control model into the TRNSYS simulation model to evaluate potential behavioral impacts.

Ongoing work in this research area should be reviewed to determine what elements can be incorporated in future versions of BEopt. Given the need for very short time step modeling of hot water events, it is unlikely that a full-scale hot water model can be effectively implemented in BEopt, but some components or features may improve the ability of the software to model hot water systems.

\footnotetext{
${ }^{5}$ Cold water sandwich effect happens when multiple draw events occur close together. With each tank firing there is a burner firing delay after the start of flow, allowing an initial slug of cold water to pass through the exchanger. At the use point the user will experience hot water that was in the lines from the previous draw, followed by a cooled or cold volume, before hot water arrives.
} 


\section{References}

Aquacraft (2008). "Hot \& Cold Water Data from EPA Retrofit Studies - EBMUD \& Seattle." Boulder, CO: Aquacraft, Inc.

Backman, C.; Hoeschele, M. (2013). "Validation of a Hot Water Distribution Model Using Laboratory and Field Data." Alliance for Residential Building Innovation.

Copeland, C. (2014). “Energy-Water Nexus: The Water Sector's Energy Use” Congressional Research Service report \# R43200 Accessed September

2014: http://fas.org/sgp/crs/misc/R43200.pdf.

DEG (2003). Progress Report on Building America Residential Water Heating Research. Annual report to CARB, Steven Winter Associates. Davis, CA: Davis Energy Group

DEG. (2006). Prototype Floor Plans - Hot Water Distribution System Layouts. Report to Lawrence Berkeley National Laboratory under funding by the California Energy Commission. Davis, CA: Davis Energy Group.

Henderson, H.; Wade, J. (2014) "Disaggregating Hot Water Use and Predicting Hot Water Waste in Five Test Homes" ARIES Collaborative

Hendron, R.; Burch, J. (2008). "Development of Standardized Hot Water Event Schedules for Residential Buildings.” NREL/PR-550-40874. Presented at the 2008 Energy Sustainability 2007 conference. Accessed September 2014: http://www.nrel.gov/docs/fy08osti/40874.pdf.

Hiller, C. (2006). "Hot Water Distribution System Piping Time, Water, and Energy Waste Phase I Test Results." ASHRAE Transactions 114(1): 415-425.

Klein, G. (2005). California's Water-Energy Relationship. California Energy Commission. Publication Number: CEC-700-2005-011-SF

Kosar, D.; Glanville, P.; Vadnal, H. (2012). Residential Water Heating Program. California Energy Commission. Publication number: CEC-500-08-060.

Lutz, J.D. (Lawrence Berkeley National Laboratory). 2008. Water Heaters and Hot Water Distribution Systems. California Energy Commission, PIER Buildings End Use Energy Efficiency. CEC-500-2005-082.

Lutz, J.; Melody, M. (2012). Typical Hot Water Draw Patterns Based on Field Data. Berkeley, CA: Lawrence Berkeley National Laboratory.

Maguire, J.; Krarti, M.; Fang, X. (2011). "An Analysis Model for Domestic Hot Water Distribution Systems," NREL/CP-5500-51674. Accessed September 2014: http://www.nrel.gov/docs/fy12osti/51674.pdf 
Mayer, P.; DeOreo, W. (1999). "Residential End Uses of Water," Prepared for the American Water Works Association, Boulder, CO: Aquacraft, Inc.

Sherman, T. (2014). "Disaggregating Residential Shower Warm-Up Waste" Scottsdale, AZ: ShowerStart LLC.

Springer, D.; Rainer, L.; Hoeschele, M. (2008). "HWSIM: Development and Validation of a Residential Hot Water Distribution System Model." Proceedings of the 2008 ACEEE Summer Study on Energy Efficiency in Buildings.

Wilson, E.; Engebrecht Metzger, C.; Horowitz, S.; Hendron, R.; (2014). 2014 Building America House Simulation Protocols. NREL/TP-5500-60988. Golden, CO: National Renewable Energy Laboratory.

Wilson, W.; Leipzig, T.; Griffiths-Sattenspiel, B. (2012). "Burning Our Rivers: The Water Footprint of Electricity." Portland, OR: River Network. 


\section{Appendix A: TRNSYS Model Results}

Included in Table 4 are the compiled annual results for the 124 selected model cases.

Table 4. Compiled Annual Results

\begin{tabular}{|c|c|c|c|c|c|}
\hline Parametric Options for Run ID: & 1 & 2 & 3 & 4 & 5 \\
\hline Climate & Chicago & Chicago & Denver & Denver & Chicago \\
\hline Occupants & 2 & 4 & 2 & 4 & 2 \\
\hline Distribution Type & $\begin{array}{l}\text { Trunk \& } \\
\text { Branch }\end{array}$ & $\begin{array}{l}\text { Trunk \& } \\
\text { Branch }\end{array}$ & $\begin{array}{c}\text { Trunk \& } \\
\text { Branch }\end{array}$ & $\begin{array}{l}\text { Trunk \& } \\
\text { Branch }\end{array}$ & $\begin{array}{c}\text { Trunk \& } \\
\text { Branch }\end{array}$ \\
\hline \multicolumn{6}{|l|}{ Recirculation Type } \\
\hline Insulation & None & None & None & None & Ins \\
\hline Plumbing Practice & $\begin{array}{l}\text { Typical } \\
\text { (Waste) }\end{array}$ & $\begin{array}{l}\text { Typical } \\
\text { (Waste) }\end{array}$ & $\begin{array}{c}\text { Typical } \\
\text { (Waste) }\end{array}$ & $\begin{array}{l}\text { Typical } \\
\text { (Waste) }\end{array}$ & Compact \\
\hline \multicolumn{6}{|l|}{ Annual Results: } \\
\hline Water Heater Energy Use (kWh) & 3,365 & 4,889 & 3,343 & 4,932 & 3,201 \\
\hline Hot Water Draw (gal) & 19,160 & 29,437 & 19,843 & 30,607 & 18,071 \\
\hline Total Water Use (gal) & 20,851 & 32,070 & 21,605 & 33,375 & 19,917 \\
\hline Energy Delivered (kWh) & 2,946 & 4,472 & 2,927 & 4,518 & 2,782 \\
\hline Tank Losses $(\mathrm{kWh})$ & 415.5 & 414.1 & 412.6 & 410.7 & 415.8 \\
\hline Use Point Wasted Energy (kWh) & 330.5 & 507.7 & 330.4 & 518.0 & 252.7 \\
\hline Wasted Hot Water (gal) & 3,590 & 5,470 & 3,871 & 5,801 & 2,509 \\
\hline Pipe Loss, All (kWh) & 325.1 & 466.4 & 328.6 & 466.5 & 190.0 \\
\hline \multicolumn{6}{|l|}{ Recirc Losses (kWh) } \\
\hline Total Distribution Losses (kWh) & 655.6 & 974.2 & 659.0 & 984.5 & 442.8 \\
\hline Total Useful Energy (kWh) & 2,294 & 3,501 & 2,271 & 3,537 & 2,343 \\
\hline Useful Energy ( $\%$ of water heater energy use) & $68.2 \%$ & $71.6 \%$ & $67.9 \%$ & $71.7 \%$ & $73.2 \%$ \\
\hline Pipe Losses ( $\%$ of water heater energy use) & $9.7 \%$ & $9.5 \%$ & $9.8 \%$ & $9.5 \%$ & $5.9 \%$ \\
\hline Wasted Energy ( $\%$ of water heater energy use) & $9.8 \%$ & $10.4 \%$ & $9.9 \%$ & $10.5 \%$ & $7.9 \%$ \\
\hline Water Heater Losses ( $\%$ of water heater energy use) & $12.3 \%$ & $8.5 \%$ & $12.3 \%$ & $8.3 \%$ & $13.0 \%$ \\
\hline Water Waste ( $\%$ of total hot water) & $18.7 \%$ & $18.6 \%$ & $19.5 \%$ & $19.0 \%$ & $13.9 \%$ \\
\hline Wasted Water (\% of useful water delivered) & $23.1 \%$ & $22.8 \%$ & $24.2 \%$ & $23.4 \%$ & $16.1 \%$ \\
\hline Distribution Losses ( $\%$ of water heater energy use) & $19.5 \%$ & $19.9 \%$ & $19.7 \%$ & $20.0 \%$ & $13.8 \%$ \\
\hline Distribution Losses ( $\%$ of useful energy delivered) & $28.6 \%$ & $27.8 \%$ & $29.0 \%$ & $27.8 \%$ & $18.9 \%$ \\
\hline
\end{tabular}




\begin{tabular}{|c|c|c|c|c|c|c|c|c|}
\hline 6 & 7 & 8 & 9 & 10 & 11 & 12 & 13 & 14 \\
\hline Chicago & Denver & Denver & Chicago & Chicago & Denver & Denver & Chicago & Chicago \\
\hline 4 & 2 & 4 & 2 & 4 & 2 & 4 & 2 & 4 \\
\hline \multirow[t]{2}{*}{$\begin{array}{c}\text { Trunk \& } \\
\text { Branch }\end{array}$} & $\begin{array}{l}\text { Trunk \& } \\
\text { Branch }\end{array}$ & $\begin{array}{l}\text { Trunk \& } \\
\text { Branch }\end{array}$ & $\begin{array}{l}\text { Demand } \\
\text { Recirc }\end{array}$ & $\begin{array}{l}\text { Demand } \\
\text { Recirc }\end{array}$ & $\begin{array}{l}\text { Demand } \\
\text { Recirc }\end{array}$ & $\begin{array}{l}\text { Demand } \\
\text { Recirc }\end{array}$ & $\begin{array}{c}\text { Demand } \\
\text { Recirc }\end{array}$ & $\begin{array}{l}\text { Demand } \\
\text { Recirc }\end{array}$ \\
\hline & & & $\begin{array}{l}\text { Long run- } \\
\text { outs }\end{array}$ & $\begin{array}{l}\text { Long run- } \\
\text { outs }\end{array}$ & $\begin{array}{l}\text { Long run- } \\
\text { outs }\end{array}$ & $\begin{array}{l}\text { Long run- } \\
\text { outs }\end{array}$ & $\begin{array}{l}\text { Short run- } \\
\text { outs }\end{array}$ & $\begin{array}{l}\text { Short run- } \\
\text { outs }\end{array}$ \\
\hline Ins & Ins & Ins & Ins & Ins & Ins & Ins & Ins & Ins \\
\hline Compact & Compact & Compact & Compact & Compact & Compact & Compact & Compact & Compact \\
\hline 4,630 & 3,181 & 4,676 & 3,314 & 4,731 & 3,278 & 4,752 & 3,585 & 5,032 \\
\hline 27,703 & 18,740 & 28,850 & 17,144 & 26,291 & 17,577 & 27,269 & 17,032 & 26,087 \\
\hline 30,578 & 20,659 & 31,869 & 18,907 & 29,130 & 19,425 & 30,207 & 18,714 & 28,798 \\
\hline 4,212 & 2,765 & 4,261 & 2,893 & 4,310 & 2,860 & 4,333 & 3,164 & 4,611 \\
\hline 414.6 & 412.9 & 411.2 & 417.1 & 417.5 & 414.2 & 414.5 & 417.0 & 417.5 \\
\hline 373.3 & 256.7 & 386.7 & 225.0 & 302.0 & 215.6 & 312.6 & 209.6 & 269.8 \\
\hline 3,754 & 2,784 & 4,071 & 2,235 & 3,016 & 2,360 & 3,341 & 1,988 & 2,569 \\
\hline \multirow[t]{2}{*}{267.9} & 193.0 & 268.7 & 421.8 & 530.4 & 423.7 & 528.4 & 711.3 & 863.9 \\
\hline & & & 101.1 & 104.2 & 99.3 & 103.7 & 248.2 & 262.6 \\
\hline 641.2 & 449.7 & 655.4 & 646.8 & 832.4 & 639.4 & 841.0 & 920.9 & $1,133.7$ \\
\hline 3,575 & 2,318 & 3,609 & 2,250 & 3,481 & 2,224 & 3,496 & 2,247 & 3,481 \\
\hline $77.2 \%$ & $72.9 \%$ & $77.2 \%$ & $67.9 \%$ & $73.6 \%$ & $67.9 \%$ & $73.6 \%$ & $62.7 \%$ & $69.2 \%$ \\
\hline $5.8 \%$ & $6.1 \%$ & $5.7 \%$ & $12.7 \%$ & $11.2 \%$ & $12.9 \%$ & $11.1 \%$ & $19.8 \%$ & $17.2 \%$ \\
\hline $8.1 \%$ & $8.1 \%$ & $8.3 \%$ & $6.8 \%$ & $6.4 \%$ & $6.6 \%$ & $6.6 \%$ & $5.8 \%$ & $5.4 \%$ \\
\hline $9.0 \%$ & $13.0 \%$ & $8.8 \%$ & $12.6 \%$ & $8.8 \%$ & $12.6 \%$ & $8.7 \%$ & $11.6 \%$ & $8.3 \%$ \\
\hline $13.6 \%$ & $14.9 \%$ & $14.1 \%$ & $13.0 \%$ & $11.5 \%$ & $13.4 \%$ & $12.3 \%$ & $11.7 \%$ & $9.8 \%$ \\
\hline $15.7 \%$ & $17.5 \%$ & $16.4 \%$ & $15.0 \%$ & $13.0 \%$ & $15.5 \%$ & $14.0 \%$ & $13.2 \%$ & $10.9 \%$ \\
\hline $13.8 \%$ & $14.1 \%$ & $14.0 \%$ & $19.5 \%$ & $17.6 \%$ & $19.5 \%$ & $17.7 \%$ & $25.7 \%$ & $22.5 \%$ \\
\hline $17.9 \%$ & $19.4 \%$ & $18.2 \%$ & $28.7 \%$ & $23.9 \%$ & $28.7 \%$ & $24.1 \%$ & $41.0 \%$ & $32.6 \%$ \\
\hline
\end{tabular}




\begin{tabular}{|c|c|c|c|c|c|c|c|c|}
\hline 15 & 16 & 17 & 18 & 19 & 20 & 21 & 22 & 23 \\
\hline Denver & Denver & Chicago & Chicago & Denver & Denver & Chicago & Chicago & Denver \\
\hline 2 & 4 & 2 & 4 & 2 & 4 & 2 & 4 & 2 \\
\hline $\begin{array}{l}\text { Demand } \\
\text { Recirc }\end{array}$ & $\begin{array}{l}\text { Demand } \\
\text { Recirc }\end{array}$ & $\begin{array}{l}\text { Home } \\
\text { Run }\end{array}$ & $\begin{array}{l}\text { Home } \\
\text { Run }\end{array}$ & $\begin{array}{l}\text { Home } \\
\text { Run }\end{array}$ & $\begin{array}{l}\text { Home } \\
\text { Run }\end{array}$ & $\begin{array}{l}\text { Home } \\
\text { Run }\end{array}$ & $\begin{array}{l}\text { Home } \\
\text { Run }\end{array}$ & $\begin{array}{l}\text { Home } \\
\text { Run }\end{array}$ \\
\hline $\begin{array}{l}\text { Short run- } \\
\text { outs }\end{array}$ & $\begin{array}{l}\text { Short run- } \\
\text { outs }\end{array}$ & & & & & & & \\
\hline Ins & Ins & None & None & None & None & Ins & Ins & Ins \\
\hline Compact & Compact & Compact & Compact & Compact & Compact & Compact & Compact & Compact \\
\hline 3,545 & 5,052 & 3,323 & 4,850 & 3,294 & 4,887 & 3,287 & 4,777 & 3,257 \\
\hline 17,450 & 27,062 & 18,857 & 29,137 & 19,470 & 30,252 & 18,613 & 28,644 & 19,218 \\
\hline 19,215 & 29,877 & 20,655 & 31,936 & 21,342 & 33,191 & 20,495 & 31,569 & 21,175 \\
\hline 3,127 & 4,634 & 2,904 & 4,432 & 2,877 & 4,472 & 2,868 & 4,359 & 2,841 \\
\hline 414.2 & 414.4 & 415.7 & 414.4 & 412.9 & 411.0 & 415.7 & 414.5 & 413.0 \\
\hline 199.1 & 281.9 & 293.7 & 450.6 & 296.2 & 461.3 & 279.9 & 419.1 & 283.4 \\
\hline 2,096 & 2,893 & 3,156 & 4,862 & 3,433 & 5,217 & 2,964 & 4,442 & 3,237 \\
\hline 711.1 & 859.1 & 253.4 & 381.7 & 256.2 & 384.0 & 221.0 & 323.1 & 222.8 \\
\hline 243.2 & 257.7 & & & & & & & \\
\hline 910.2 & $1,141.0$ & 547.1 & 832.3 & 552.4 & 845.3 & 500.9 & 742.1 & 506.2 \\
\hline 2,220 & 3,496 & 2,360 & 3,604 & 2,328 & 3,630 & 2,370 & 3,620 & 2,338 \\
\hline $62.6 \%$ & $69.2 \%$ & $71.0 \%$ & $74.3 \%$ & $70.7 \%$ & $74.3 \%$ & $72.1 \%$ & $75.8 \%$ & $71.8 \%$ \\
\hline $20.1 \%$ & $17.0 \%$ & $7.6 \%$ & $7.9 \%$ & $7.8 \%$ & $7.9 \%$ & $6.7 \%$ & $6.8 \%$ & $6.8 \%$ \\
\hline $5.6 \%$ & $5.6 \%$ & $8.8 \%$ & $9.3 \%$ & $9.0 \%$ & $9.4 \%$ & $8.5 \%$ & $8.8 \%$ & $8.7 \%$ \\
\hline $11.7 \%$ & $8.2 \%$ & $12.5 \%$ & $8.5 \%$ & $12.5 \%$ & $8.4 \%$ & $12.6 \%$ & $8.7 \%$ & $12.7 \%$ \\
\hline $12.0 \%$ & $10.7 \%$ & $16.7 \%$ & $16.7 \%$ & $17.6 \%$ & $17.2 \%$ & $15.9 \%$ & $15.5 \%$ & $16.8 \%$ \\
\hline $13.6 \%$ & $12.0 \%$ & $20.1 \%$ & $20.0 \%$ & $21.4 \%$ & $20.8 \%$ & $18.9 \%$ & $18.4 \%$ & $20.3 \%$ \\
\hline $25.7 \%$ & $22.6 \%$ & $16.5 \%$ & $17.2 \%$ & $16.8 \%$ & $17.3 \%$ & $15.2 \%$ & $15.5 \%$ & $15.5 \%$ \\
\hline $41.0 \%$ & $32.6 \%$ & $23.2 \%$ & $23.1 \%$ & $23.7 \%$ & $23.3 \%$ & $21.1 \%$ & $20.5 \%$ & $21.7 \%$ \\
\hline
\end{tabular}




\begin{tabular}{|c|c|c|c|c|c|c|c|c|}
\hline 24 & 25 & 26 & 27 & 28 & 29 & 30 & 31 & 32 \\
\hline Denver & Chicago & Chicago & Denver & Denver & Chicago & Chicago & Denver & Denver \\
\hline 4 & 2 & 4 & 2 & 4 & 2 & 4 & 2 & 4 \\
\hline $\begin{array}{l}\text { Home } \\
\text { Run }\end{array}$ & $\begin{array}{l}\text { Home } \\
\text { Run }\end{array}$ & $\begin{array}{l}\text { Home } \\
\text { Run }\end{array}$ & $\begin{array}{l}\text { Home } \\
\text { Run }\end{array}$ & $\begin{array}{l}\text { Home } \\
\text { Run }\end{array}$ & $\begin{array}{l}\text { Home } \\
\text { Run }\end{array}$ & $\begin{array}{l}\text { Home } \\
\text { Run }\end{array}$ & $\begin{array}{l}\text { Home } \\
\text { Run }\end{array}$ & $\begin{array}{l}\text { Home } \\
\text { Run }\end{array}$ \\
\hline Ins & None & None & None & None & Ins & Ins & Ins & Ins \\
\hline Compact & $\begin{array}{l}\text { Typical } \\
\text { (Waste) }\end{array}$ & $\begin{array}{l}\text { Typical } \\
\text { (Waste) }\end{array}$ & $\begin{array}{l}\text { Typical } \\
\text { (Waste) }\end{array}$ & $\begin{array}{l}\text { Typical } \\
\text { (Waste) }\end{array}$ & $\begin{array}{l}\text { Typical } \\
\text { (Waste) }\end{array}$ & $\begin{array}{l}\text { Typical } \\
\text { (Waste) }\end{array}$ & $\begin{array}{l}\text { Typical } \\
\text { (Waste) }\end{array}$ & $\begin{array}{l}\text { Typical } \\
\text { (Waste) }\end{array}$ \\
\hline 4,818 & 3,523 & 5,140 & 3,494 & 5,162 & 3,490 & 5,070 & 3,461 & 5.098 \\
\hline 29,781 & 20,177 & 31,052 & 20,836 & 32,115 & 19,950 & 30,575 & 20,606 & 31,669 \\
\hline 32,852 & 21,869 & 33,701 & 22,602 & 34,906 & 21,732 & 33,353 & 22,461 & 34,591 \\
\hline 4,403 & 3,104 & 4,723 & 3,078 & 4,748 & 3,071 & 4,653 & 3,045 & 4,683 \\
\hline 411.1 & 415.3 & 413.8 & 412.5 & 410.5 & 415.4 & 414.0 & 412.6 & 410.6 \\
\hline 436.0 & 377.5 & 587.0 & 382.4 & 584.4 & 371.3 & 570.0 & 377.4 & 574.2 \\
\hline 4,832 & 4,595 & 6,954 & 4,943 & 7,255 & 4,403 & 6,512 & 4,747 & 6,858 \\
\hline 324.7 & 422.8 & 609.9 & 426.0 & 608.3 & 381.5 & 532.6 & 383.3 & 531.0 \\
\hline 760.7 & 800.3 & $1,196.9$ & 808.4 & $1,192.7$ & 752.8 & $1,102.6$ & 760.7 & $1,105.1$ \\
\hline 3,646 & 2,307 & 3,529 & 2,273 & 3,559 & 2,322 & 3,554 & 2,288 & 3,582 \\
\hline $75.7 \%$ & $65.5 \%$ & $68.7 \%$ & $65.1 \%$ & $68.9 \%$ & $66.5 \%$ & $70.1 \%$ & $66.1 \%$ & $70.3 \%$ \\
\hline $6.7 \%$ & $12.0 \%$ & $11.9 \%$ & $12.2 \%$ & $11.8 \%$ & $10.9 \%$ & $10.5 \%$ & $11.1 \%$ & $10.4 \%$ \\
\hline $9.0 \%$ & $10.7 \%$ & $11.4 \%$ & $10.9 \%$ & $11.3 \%$ & $10.6 \%$ & $11.2 \%$ & $10.9 \%$ & $11.3 \%$ \\
\hline $8.5 \%$ & $11.8 \%$ & $8.1 \%$ & $11.8 \%$ & $8.0 \%$ & $11.9 \%$ & $8.2 \%$ & $11.9 \%$ & $8.1 \%$ \\
\hline $16.2 \%$ & $22.8 \%$ & $22.4 \%$ & $23.7 \%$ & $22.6 \%$ & $22.1 \%$ & $21.3 \%$ & $23.0 \%$ & $21.7 \%$ \\
\hline $19.4 \%$ & $29.5 \%$ & $28.9 \%$ & $31.1 \%$ & $29.2 \%$ & $28.3 \%$ & $27.1 \%$ & $29.9 \%$ & $27.6 \%$ \\
\hline $15.8 \%$ & $22.7 \%$ & $23.3 \%$ & $23.1 \%$ & $23.1 \%$ & $21.6 \%$ & $21.7 \%$ & $22.0 \%$ & $21.7 \%$ \\
\hline $20.9 \%$ & $34.7 \%$ & $33.9 \%$ & $35.6 \%$ & $33.5 \%$ & $32.4 \%$ & $31.0 \%$ & $33.2 \%$ & $30.9 \%$ \\
\hline
\end{tabular}




\begin{tabular}{|c|c|c|c|c|c|c|c|c}
\hline 33 & 34 & 35 & 36 & 37 & 38 & 39 & 40 & 41 \\
\hline Chicago & Chicago & Denver & Denver & Chicago & Chicago & Denver & Denver & Chicago \\
\hline 2 & 4 & 2 & 4 & 2 & 4 & 2 & 4 & 2 \\
\hline Hybrid & Hybrid & Hybrid & Hybrid & Hybrid & Hybrid & Hybrid & Hybrid & Hybrid \\
\hline & & & & & & & & \\
\hline None & None & None & None & Ins & Ins & Ins & Ins & None \\
\hline Compact & Compact & Compact & Compact & Compact & Compact & Compact & Compact & $\begin{array}{c}\text { Typical } \\
\text { (Waste) }\end{array}$ \\
\hline & & & & & & & & \\
\hline 3,241 & 4,719 & 3,216 & 4,756 & 3,210 & 4,653 & 3,187 & 4,694 & 3,435 \\
\hline 18,335 & 28,295 & 18,967 & 29,389 & 18,126 & 27,843 & 18,775 & 28,954 & 19,603 \\
\hline 20,184 & 31,187 & 20,894 & 32,420 & 20,038 & 30,829 & 20,764 & 32,088 & 21,339 \\
\hline 2,822 & 4,301 & 2,799 & 4,342 & 2,791 & 4,235 & 2,771 & 4,279 & 3,016 \\
\hline 415.7 & 414.4 & 412.9 & 411.1 & 415.8 & 414.6 & 412.9 & 411.2 & 415.4 \\
\hline 256.1 & 390.2 & 262.7 & 401.4 & 245.4 & 360.7 & 255.0 & 377.0 & 357.6 \\
\hline 2,626 & 4,026 & 2,926 & 4,354 & 2,465 & 3,636 & 2,786 & 3,990 & 3,945 \\
\hline 197.0 & 292.2 & 200.1 & 294.2 & 171.6 & 245.6 & 174.3 & 246.5 & 327.2 \\
\hline & & & & & & & & \\
\hline 453.0 & 682.4 & 462.8 & 695.6 & 417.0 & 606.3 & 429.4 & 623.5 & 684.9 \\
\hline 2,372 & 3,622 & 2,340 & 3,649 & 2,377 & 3,632 & 2,345 & 3,659 & 2,335 \\
\hline $73.2 \%$ & $76.8 \%$ & $72.8 \%$ & $76.7 \%$ & $74.1 \%$ & $78.1 \%$ & $73.6 \%$ & $78.0 \%$ & $68.0 \%$ \\
\hline $6.1 \%$ & $6.2 \%$ & $6.2 \%$ & $6.2 \%$ & $5.3 \%$ & $5.3 \%$ & $5.5 \%$ & $5.3 \%$ & $9.5 \%$ \\
\hline $7.9 \%$ & $8.3 \%$ & $8.2 \%$ & $8.4 \%$ & $7.6 \%$ & $7.8 \%$ & $8.0 \%$ & $8.0 \%$ & $10.4 \%$ \\
\hline $12.8 \%$ & $8.8 \%$ & $12.8 \%$ & $8.6 \%$ & $13.0 \%$ & $8.9 \%$ & $13.0 \%$ & $8.8 \%$ & $12.1 \%$ \\
\hline $14.3 \%$ & $14.2 \%$ & $15.4 \%$ & $14.8 \%$ & $13.6 \%$ & $13.1 \%$ & $14.8 \%$ & $13.8 \%$ & $20.1 \%$ \\
\hline $16.7 \%$ & $16.6 \%$ & $18.2 \%$ & $17.4 \%$ & $15.7 \%$ & $15.0 \%$ & $17.4 \%$ & $16.0 \%$ & $25.2 \%$ \\
\hline $14.0 \%$ & $14.5 \%$ & $14.4 \%$ & $14.6 \%$ & $13.0 \%$ & $13.0 \%$ & $13.5 \%$ & $13.3 \%$ & $19.9 \%$ \\
\hline $19.1 \%$ & $18.8 \%$ & $19.8 \%$ & $19.1 \%$ & $17.5 \%$ & $16.7 \%$ & $18.3 \%$ & $17.0 \%$ & $29.3 \%$ \\
\hline & & & & & & & &
\end{tabular}




\begin{tabular}{c|c|c|c|c|c|c|c|c}
\hline 42 & 43 & 44 & 45 & 46 & 47 & 48 & 49 & 50 \\
\hline Chicago & Denver & Denver & Chicago & Chicago & Denver & Denver & $\begin{array}{c}\text { Phoenix } \\
\text { Phoenix }\end{array}$ \\
\hline 4 & 2 & 4 & 2 & 4 & 2 & 4 & 2 & 4 \\
\hline Hybrid & Hybrid & Hybrid & Hybrid & Hybrid & Hybrid & Hybrid & $\begin{array}{c}\text { Trunk \& } \\
\text { Branch }\end{array}$ & $\begin{array}{c}\text { Trunk \& } \\
\text { Branch }\end{array}$ \\
\hline & & & & & & & & \\
\hline None & None & None & Ins & Ins & Ins & Ins & None & None \\
\hline Typical & Typical & Typical & Typical & Typical & Typical & Typical & Typical & Typical \\
(Waste) & (Waste) & (Waste) & (Waste) & (Waste) & (Waste) & (Waste) & (Waste) & (Waste) \\
\hline & & & & & & & & \\
\hline 4,982 & 3,409 & 5,017 & 3,405 & 4,923 & 3,381 & 4,956 & 1,928 & 2,950 \\
\hline 30,024 & 20,278 & 31,166 & 19,407 & 29,617 & 20,077 & 30,730 & 16,975 & 27,407 \\
\hline 32,734 & 22,086 & 34,015 & 21,199 & 32,422 & 21,949 & 33,677 & 20,370 & 32,825 \\
\hline 4,564 & 2,993 & 4,603 & 2,986 & 4,505 & 2,965 & 4,542 & 1,628 & 2,650 \\
\hline 414.0 & 412.6 & 410.6 & 415.5 & 414.2 & 412.7 & 410.8 & 296.5 & 296.2 \\
\hline 537.1 & 365.1 & 548.1 & 348.7 & 518.8 & 357.9 & 527.0 & 106.7 & 191.2 \\
\hline 5,786 & 4,300 & 6,172 & 3,775 & 5,429 & 4,129 & 5,778 & 2,740 & 4,250 \\
\hline 456.2 & 330.1 & 456.1 & 299.3 & 404.7 & 301.7 & 403.4 & 259.7 & 384.0 \\
\hline & & & & & & & & \\
\hline 993.4 & 695.2 & $1,004.2$ & 648.0 & 923.4 & 659.6 & 930.5 & 366.3 & 575.2 \\
\hline 3,574 & 2,301 & 3,602 & 2,342 & 3,585 & 2,309 & 3,615 & 1,265 & 2,078 \\
\hline $71.7 \%$ & $67.5 \%$ & $71.8 \%$ & $68.8 \%$ & $72.8 \%$ & $68.3 \%$ & $72.9 \%$ & $65.6 \%$ & $70.5 \%$ \\
\hline $9.2 \%$ & $9.7 \%$ & $9.1 \%$ & $8.8 \%$ & $8.2 \%$ & $8.9 \%$ & $8.1 \%$ & $13.5 \%$ & $13.0 \%$ \\
\hline $10.8 \%$ & $10.7 \%$ & $10.9 \%$ & $10.2 \%$ & $10.5 \%$ & $10.6 \%$ & $10.6 \%$ & $5.5 \%$ & $6.5 \%$ \\
\hline $8.3 \%$ & $12.1 \%$ & $8.2 \%$ & $12.2 \%$ & $8.4 \%$ & $12.2 \%$ & $8.3 \%$ & $15.4 \%$ & $10.0 \%$ \\
\hline $19.3 \%$ & $21.2 \%$ & $19.8 \%$ & $19.4 \%$ & $18.3 \%$ & $20.6 \%$ & $18.8 \%$ & $16.1 \%$ & $15.5 \%$ \\
\hline $23.9 \%$ & $26.9 \%$ & $24.7 \%$ & $24.1 \%$ & $22.4 \%$ & $25.9 \%$ & $23.2 \%$ & $19.3 \%$ & $18.4 \%$ \\
\hline $19.9 \%$ & $20.4 \%$ & $20.0 \%$ & $19.0 \%$ & $18.8 \%$ & $19.5 \%$ & $18.8 \%$ & $19.0 \%$ & $19.5 \%$ \\
\hline $27.8 \%$ & $30.2 \%$ & $27.9 \%$ & $27.7 \%$ & $25.8 \%$ & $28.6 \%$ & $25.7 \%$ & $29.0 \%$ & $27.7 \%$ \\
\hline
\end{tabular}




\begin{tabular}{|c|c|c|c|c|c|c|c|c|}
\hline 51 & 52 & 53 & 54 & 55 & 56 & 57 & 58 & 59 \\
\hline Houston & Houston & Atlanta & Atlanta & Phoenix & Phoenix & Houston & Houston & Atlanta \\
\hline 2 & 4 & 2 & 4 & 2 & 4 & 2 & 4 & 2 \\
\hline $\begin{array}{l}\text { Trunk \& } \\
\text { Branch }\end{array}$ & $\begin{array}{l}\text { Trunk \& } \\
\text { Branch }\end{array}$ & $\begin{array}{l}\text { Trunk \& } \\
\text { Branch }\end{array}$ & $\begin{array}{l}\text { Trunk \& } \\
\text { Branch }\end{array}$ & $\begin{array}{l}\text { Trunk \& } \\
\text { Branch }\end{array}$ & $\begin{array}{l}\text { Trunk \& } \\
\text { Branch }\end{array}$ & $\begin{array}{c}\text { Trunk \& } \\
\text { Branch }\end{array}$ & $\begin{array}{c}\text { Trunk \& } \\
\text { Branch }\end{array}$ & $\begin{array}{c}\text { Trunk \& } \\
\text { Branch }\end{array}$ \\
\hline None & None & None & None & Ins & Ins & Ins & Ins & Ins \\
\hline $\begin{array}{l}\text { Typical } \\
\text { (Waste) }\end{array}$ & $\begin{array}{l}\text { Typical } \\
\text { (Waste) }\end{array}$ & $\begin{array}{l}\text { Typical } \\
\text { (Waste) }\end{array}$ & $\begin{array}{r}\text { Typical } \\
\text { (Waste) }\end{array}$ & Compact & Compact & Compact & Compact & Compact \\
\hline 2.257 & 3.300 & 2776 & 4167 & 1843 & 2811 & 155 & 3.48 & 2650 \\
\hline 17,856 & 27,774 & 18,822 & 30,196 & 16,107 & 26,012 & 16,887 & 26,256 & 17,801 \\
\hline 20,451 & 31,944 & 21,007 & 33,659 & 19,726 & 31,777 & 19,691 & 30,743 & 20,181 \\
\hline 1,900 & 2,952 & 2,362 & 3,754 & 1,542 & 2,512 & 1,798 & 2,792 & 2,236 \\
\hline 353.4 & 353.1 & 410.5 & 409.3 & 296.6 & 296.3 & 353.5 & 353.3 & 410.6 \\
\hline 130.2 & 219.9 & 198.9 & 367.7 & 85.8 & 149.8 & 104.0 & 170.8 & 158.7 \\
\hline 3,004 & 4,585 & 3,283 & 5,563 & 1,935 & 2,956 & 2,078 & 3,147 & 2,295 \\
\hline 297.5 & 428.5 & 333.4 & 481.4 & 163.8 & 235.7 & 183.3 & 259.9 & 203.2 \\
\hline 427.7 & 648.4 & 532.3 & 849.1 & 249.6 & 385.5 & 287.3 & 430.7 & 361.9 \\
\hline 1,476 & 2,308 & 1,833 & 2,909 & 1,297 & 2,130 & 1,514 & 2,364 & 1,878 \\
\hline $65.4 \%$ & $69.7 \%$ & $66.0 \%$ & $69.8 \%$ & $70.4 \%$ & $75.7 \%$ & $70.3 \%$ & $75.1 \%$ & $70.8 \%$ \\
\hline $13.2 \%$ & $12.9 \%$ & $12.0 \%$ & $11.6 \%$ & $8.9 \%$ & $8.4 \%$ & $8.5 \%$ & $8.3 \%$ & $7.7 \%$ \\
\hline $5.8 \%$ & $6.6 \%$ & $7.2 \%$ & $8.8 \%$ & $4.7 \%$ & $5.3 \%$ & $4.8 \%$ & $5.4 \%$ & $6.0 \%$ \\
\hline $15.7 \%$ & $10.7 \%$ & $14.8 \%$ & $9.8 \%$ & $16.1 \%$ & $10.5 \%$ & $16.4 \%$ & $11.2 \%$ & $15.5 \%$ \\
\hline $16.8 \%$ & $16.5 \%$ & $17.4 \%$ & $18.4 \%$ & $12.0 \%$ & $11.4 \%$ & $12.3 \%$ & $12.0 \%$ & $12.9 \%$ \\
\hline $20.2 \%$ & $19.8 \%$ & $21.1 \%$ & $22.6 \%$ & $13.7 \%$ & $12.8 \%$ & $14.0 \%$ & $13.6 \%$ & $14.8 \%$ \\
\hline $19.0 \%$ & $19.6 \%$ & $19.2 \%$ & $20.4 \%$ & $13.5 \%$ & $13.7 \%$ & $13.3 \%$ & $13.7 \%$ & $13.7 \%$ \\
\hline $29.0 \%$ & $28.1 \%$ & $29.0 \%$ & $29.2 \%$ & $19.2 \%$ & $18.1 \%$ & $19.0 \%$ & $18.2 \%$ & $19.3 \%$ \\
\hline
\end{tabular}




\begin{tabular}{|c|c|c|c|c|c|c|c|c|}
\hline 60 & 61 & 62 & 63 & 64 & 65 & 66 & 67 & 68 \\
\hline Atlanta & Phoenix & Phoenix & Houston & Houston & Atlanta & Atlanta & Phoenix & Phoenix \\
\hline 4 & 2 & 4 & 2 & 4 & 2 & 4 & 2 & 4 \\
\hline \multirow[t]{2}{*}{$\begin{array}{c}\text { Trunk \& } \\
\text { Branch }\end{array}$} & $\begin{array}{l}\text { Demand } \\
\text { Recirc }\end{array}$ & $\begin{array}{c}\text { Demand } \\
\text { Recirc }\end{array}$ & $\begin{array}{c}\text { Demand } \\
\text { Recirc }\end{array}$ & $\begin{array}{c}\text { Demand } \\
\text { Recirc }\end{array}$ & $\begin{array}{c}\text { Demand } \\
\text { Recirc }\end{array}$ & $\begin{array}{c}\text { Demand } \\
\text { Recirc }\end{array}$ & $\begin{array}{l}\text { Demand } \\
\text { Recirc }\end{array}$ & $\begin{array}{c}\text { Demand } \\
\text { Recirc }\end{array}$ \\
\hline & $\begin{array}{l}\text { Long run- } \\
\text { outs }\end{array}$ & $\begin{array}{l}\text { Long run- } \\
\text { outs }\end{array}$ & $\begin{array}{l}\text { Long run- } \\
\text { outs }\end{array}$ & $\begin{array}{l}\text { Long run- } \\
\text { outs }\end{array}$ & $\begin{array}{l}\text { Long run- } \\
\text { outs }\end{array}$ & $\begin{array}{l}\text { Long run- } \\
\text { outs }\end{array}$ & $\begin{array}{l}\text { Short run- } \\
\text { outs }\end{array}$ & $\begin{array}{l}\text { Short run- } \\
\text { outs }\end{array}$ \\
\hline Ins & Ins & Ins & Ins & Ins & Ins & Ins & Ins & Ins \\
\hline Compact & Compact & Compact & Compact & Compact & Compact & Compact & Compact & Compact \\
\hline 3,964 & 1,954 & 2,916 & 2,293 & 3,287 & 2,800 & 4,093 & 2,146 & 3,138 \\
\hline 28,557 & 15,414 & 25,016 & 16,140 & 25,309 & 17,033 & 27,276 & 15,401 & 24,935 \\
\hline 32,329 & 18,934 & 30,755 & 18,826 & 29,637 & 19,289 & 30,918 & 18,762 & 30,457 \\
\hline 3,551 & 1,654 & 2,616 & 1,936 & 2,930 & 2,386 & 3,678 & 1,847 & 2,838 \\
\hline 409.6 & 295.8 & 296.4 & 353.1 & 353.6 & 410.9 & 411.2 & 295.8 & 296.5 \\
\hline 290.2 & 81.3 & 128.6 & 103.5 & 163.7 & 153.0 & 253.2 & 79.5 & 122.8 \\
\hline 3,968 & 1,787 & 2,716 & 1,955 & 2,988 & 2,181 & 3,506 & 1,633 & 2,427 \\
\hline \multirow[t]{2}{*}{286.0} & 329.1 & 427.6 & 382.8 & 485.4 & 432.2 & 544.9 & 531.9 & 667.5 \\
\hline & 61.1 & 63.6 & 80.9 & 84.2 & 94.9 & 99.5 & 152.9 & 161.9 \\
\hline 576.3 & 410.4 & 556.2 & 486.4 & 649.1 & 585.1 & 798.1 & 611.4 & 790.3 \\
\hline 2,978 & 1,247 & 2,064 & 1,453 & 2,285 & 1,804 & 2,884 & 1,239 & 2,052 \\
\hline $75.1 \%$ & $63.9 \%$ & $70.8 \%$ & $63.4 \%$ & $69.5 \%$ & $64.4 \%$ & $70.5 \%$ & $57.7 \%$ & $65.4 \%$ \\
\hline $7.2 \%$ & $16.8 \%$ & $14.7 \%$ & $16.7 \%$ & $14.8 \%$ & $15.4 \%$ & $13.3 \%$ & $24.8 \%$ & $21.3 \%$ \\
\hline $7.3 \%$ & $4.2 \%$ & $4.4 \%$ & $4.5 \%$ & $5.0 \%$ & $5.5 \%$ & $6.2 \%$ & $3.7 \%$ & $3.9 \%$ \\
\hline $10.3 \%$ & $15.1 \%$ & $10.2 \%$ & $15.4 \%$ & $10.8 \%$ & $14.7 \%$ & $10.0 \%$ & $13.8 \%$ & $9.4 \%$ \\
\hline $13.9 \%$ & $11.6 \%$ & $10.9 \%$ & $12.1 \%$ & $11.8 \%$ & $12.8 \%$ & $12.9 \%$ & $10.6 \%$ & $9.7 \%$ \\
\hline $16.1 \%$ & $13.1 \%$ & $12.2 \%$ & $13.8 \%$ & $13.4 \%$ & $14.7 \%$ & $14.7 \%$ & $11.9 \%$ & $10.8 \%$ \\
\hline $14.5 \%$ & $21.0 \%$ & $19.1 \%$ & $21.2 \%$ & $19.7 \%$ & $20.9 \%$ & $19.5 \%$ & $28.5 \%$ & $25.2 \%$ \\
\hline $19.4 \%$ & $32.9 \%$ & $27.0 \%$ & $33.5 \%$ & $28.4 \%$ & $32.4 \%$ & $27.7 \%$ & $49.4 \%$ & $38.5 \%$ \\
\hline
\end{tabular}




\begin{tabular}{|c|c|c|c|c|c|c|c|c|}
\hline 69 & 70 & 71 & 72 & 73 & 74 & 75 & 76 & 77 \\
\hline Houston & Houston & Atlanta & Atlanta & Phoenix & Phoenix & Houston & Houston & Atlanta \\
\hline 2 & 4 & 2 & 4 & 2 & 4 & 2 & 4 & 2 \\
\hline $\begin{array}{l}\text { Demand } \\
\text { Recirc }\end{array}$ & $\begin{array}{l}\text { Demand } \\
\text { Recirc }\end{array}$ & $\begin{array}{c}\text { Demand } \\
\text { Recirc }\end{array}$ & $\begin{array}{c}\text { Demand } \\
\text { Recirc }\end{array}$ & $\begin{array}{l}\text { Home } \\
\text { Run }\end{array}$ & $\begin{array}{l}\text { Home } \\
\text { Run }\end{array}$ & $\begin{array}{l}\text { Home } \\
\text { Run }\end{array}$ & $\begin{array}{l}\text { Home } \\
\text { Run }\end{array}$ & $\begin{array}{l}\text { Home } \\
\text { Run }\end{array}$ \\
\hline $\begin{array}{l}\text { Short run- } \\
\text { outs }\end{array}$ & $\begin{array}{l}\text { Short run- } \\
\text { outs }\end{array}$ & $\begin{array}{l}\text { Short run- } \\
\text { outs }\end{array}$ & $\begin{array}{l}\text { Short run- } \\
\text { outs }\end{array}$ & & & & & \\
\hline Ins & Ins & Ins & Ins & None & None & None & None & None \\
\hline Compact & Compact & Compact & Compact & Compact & Compact & Compact & Compact & Compact \\
\hline 2,530 & 3,553 & 3,066 & 4,394 & 1,899 & 2,914 & 2,222 & 3,272 & 2,739 \\
\hline 16,105 & 25,209 & 16,930 & 27,124 & 16,657 & 27,007 & 17,500 & 27,407 & 18,501 \\
\hline 18,662 & 29,354 & 19,080 & 30,607 & 20,220 & 32,731 & 20,251 & 31,810 & 20,818 \\
\hline 2,173 & 3,196 & 2,652 & 3,980 & 1,599 & 2,614 & 1,865 & 2,916 & 2,324 \\
\hline 353.0 & 353.7 & 410.8 & 411.2 & 296.5 & 296.3 & 353.5 & 353.2 & 410.6 \\
\hline 103.0 & 156.3 & 144.2 & 240.6 & 94.9 & 169.8 & 117.3 & 191.8 & 178.4 \\
\hline 1,804 & 2,663 & 1,945 & 3,161 & 2,407 & 3,833 & 2,626 & 4,094 & 2,889 \\
\hline 631.4 & 768.3 & 713.8 & 869.6 & 208.3 & 321.9 & 235.0 & 355.5 & 263.7 \\
\hline 202.1 & 211.5 & 234.6 & 245.2 & & & & & \\
\hline 734.3 & 924.6 & 858.0 & $1,110.2$ & 303.2 & 491.7 & 352.3 & 547.3 & 442.2 \\
\hline 1,442 & 2,275 & 1,797 & 2,873 & 1,299 & 2,126 & 1,516 & 2,372 & 1,886 \\
\hline $57.0 \%$ & $64.0 \%$ & $58.6 \%$ & $65.4 \%$ & $68.4 \%$ & $73.0 \%$ & $68.2 \%$ & $72.5 \%$ & $68.9 \%$ \\
\hline $25.0 \%$ & $21.6 \%$ & $23.3 \%$ & $19.8 \%$ & $11.0 \%$ & $11.0 \%$ & $10.6 \%$ & $10.9 \%$ & $9.6 \%$ \\
\hline $4.1 \%$ & $4.4 \%$ & $4.7 \%$ & $5.5 \%$ & $5.0 \%$ & $5.8 \%$ & $5.3 \%$ & $5.9 \%$ & $6.5 \%$ \\
\hline $14.0 \%$ & $10.0 \%$ & $13.4 \%$ & $9.4 \%$ & $15.6 \%$ & $10.2 \%$ & $15.9 \%$ & $10.8 \%$ & $15.0 \%$ \\
\hline $11.2 \%$ & $10.6 \%$ & $11.5 \%$ & $11.7 \%$ & $14.4 \%$ & $14.2 \%$ & $15.0 \%$ & $14.9 \%$ & $15.6 \%$ \\
\hline $12.6 \%$ & $11.8 \%$ & $13.0 \%$ & $13.2 \%$ & $16.9 \%$ & $16.5 \%$ & $17.7 \%$ & $17.6 \%$ & $18.5 \%$ \\
\hline $29.0 \%$ & $26.0 \%$ & $28.0 \%$ & $25.3 \%$ & $16.0 \%$ & $16.9 \%$ & $15.9 \%$ & $16.7 \%$ & $16.1 \%$ \\
\hline $50.9 \%$ & $40.6 \%$ & $47.7 \%$ & $38.6 \%$ & $23.3 \%$ & $23.1 \%$ & $23.2 \%$ & $23.1 \%$ & $23.4 \%$ \\
\hline
\end{tabular}




\begin{tabular}{|c|c|c|c|c|c|c|c|c|}
\hline 78 & 79 & 80 & 81 & 82 & 83 & 84 & 85 & 86 \\
\hline Atlanta & Phoenix & Phoenix & Houston & Houston & Atlanta & Atlanta & Phoenix & Phoenix \\
\hline 4 & 2 & 4 & 2 & 4 & 2 & 4 & 2 & 4 \\
\hline $\begin{array}{l}\text { Home } \\
\text { Run }\end{array}$ & $\begin{array}{l}\text { Home } \\
\text { Run }\end{array}$ & $\begin{array}{c}\text { Home } \\
\text { Run }\end{array}$ & $\begin{array}{c}\text { Home } \\
\text { Run }\end{array}$ & $\begin{array}{c}\text { Home } \\
\text { Run }\end{array}$ & $\begin{array}{c}\text { Home } \\
\text { Run }\end{array}$ & $\begin{array}{c}\text { Home } \\
\text { Run }\end{array}$ & $\begin{array}{l}\text { Home } \\
\text { Run }\end{array}$ & $\begin{array}{c}\text { Home } \\
\text { Run }\end{array}$ \\
\hline None & Ins & Ins & Ins & Ins & Ins & Ins & None & None \\
\hline Compact & Compact & Compact & Compact & Compact & Compact & Compact & $\begin{array}{l}\text { Typical } \\
\text { (Waste) }\end{array}$ & $\begin{array}{l}\text { Typical } \\
\text { (Waste) }\end{array}$ \\
\hline 4,125 & 1,876 & 2,869 & 2,197 & 3,224 & 2,709 & 4,064 & 2,006 & 3,069 \\
\hline 29,817 & 16,417 & 26,546 & 17,269 & 26,947 & 18,256 & 29,327 & 17,740 & 28,575 \\
\hline 33,500 & 20,086 & 32,446 & 20,121 & 31,513 & 20,680 & 33,177 & 21,128 & 34,041 \\
\hline 3,712 & 1,576 & 2,570 & 1,840 & 2,868 & 2,294 & 3,651 & 1,706 & 2,769 \\
\hline 409.4 & 296.6 & 296.4 & 353.5 & 353.3 & 410.6 & 409.5 & 296.5 & 296.2 \\
\hline 325.0 & 91.1 & 158.7 & 113.4 & 181.8 & 172.0 & 307.3 & 113.1 & 202.3 \\
\hline 4,975 & 2,246 & 3,474 & 2,468 & 3,743 & 2,716 & 4,582 & 3,602 & 5,535 \\
\hline 399.0 & 182.7 & 274.3 & 206.2 & 303.8 & 230.6 & 338.5 & 334.5 & 497.0 \\
\hline 723.9 & 273.8 & 433.0 & 319.6 & 485.6 & 402.6 & 645.8 & 447.5 & 699.3 \\
\hline 2,991 & 1,306 & 2,140 & 1,524 & 2,386 & 1,895 & 3,009 & 1,262 & 2,073 \\
\hline $72.5 \%$ & $69.6 \%$ & $74.6 \%$ & $69.4 \%$ & $74.0 \%$ & $70.0 \%$ & $74.0 \%$ & $62.9 \%$ & $67.6 \%$ \\
\hline $9.7 \%$ & $9.7 \%$ & $9.6 \%$ & $9.4 \%$ & $9.4 \%$ & $8.5 \%$ & $8.3 \%$ & $16.7 \%$ & $16.2 \%$ \\
\hline $7.9 \%$ & $4.9 \%$ & $5.5 \%$ & $5.2 \%$ & $5.6 \%$ & $6.3 \%$ & $7.6 \%$ & $5.6 \%$ & $6.6 \%$ \\
\hline $9.9 \%$ & $15.8 \%$ & $10.3 \%$ & $16.1 \%$ & $11.0 \%$ & $15.2 \%$ & $10.1 \%$ & $14.8 \%$ & $9.7 \%$ \\
\hline $16.7 \%$ & $13.7 \%$ & $13.1 \%$ & $14.3 \%$ & $13.9 \%$ & $14.9 \%$ & $15.6 \%$ & $20.3 \%$ & $19.4 \%$ \\
\hline $20.0 \%$ & $15.9 \%$ & $15.1 \%$ & $16.7 \%$ & $16.1 \%$ & $17.5 \%$ & $18.5 \%$ & $25.5 \%$ & $24.0 \%$ \\
\hline $17.6 \%$ & $14.6 \%$ & $15.1 \%$ & $14.5 \%$ & $15.1 \%$ & $14.9 \%$ & $15.9 \%$ & $22.3 \%$ & $22.8 \%$ \\
\hline $24.2 \%$ & $21.0 \%$ & $20.2 \%$ & $21.0 \%$ & $20.4 \%$ & $21.2 \%$ & $21.5 \%$ & $35.5 \%$ & $33.7 \%$ \\
\hline
\end{tabular}




\begin{tabular}{c|c|c|c|c|c|c|c|c}
\hline 87 & 88 & 89 & 90 & 91 & 92 & 93 & 94 & 95 \\
\hline $\begin{array}{c}\text { Houston } \\
2\end{array}$ & Houston & Atlanta & Atlanta & Phoenix & Phoenix & Houston & Houston & Atlanta \\
\hline $\begin{array}{c}\text { Home } \\
\text { Run }\end{array}$ & $\begin{array}{c}\text { Home } \\
\text { Run }\end{array}$ & $\begin{array}{c}\text { Home } \\
\text { Run }\end{array}$ & $\begin{array}{c}\text { Home } \\
\text { Run }\end{array}$ & $\begin{array}{c}\text { Home } \\
\text { Run }\end{array}$ & $\begin{array}{c}\text { Home } \\
\text { Run }\end{array}$ & $\begin{array}{c}\text { Home } \\
\text { Run }\end{array}$ & $\begin{array}{c}\text { Home } \\
\text { Run }\end{array}$ & $\begin{array}{c}\text { Home } \\
\text { Run }\end{array}$ \\
\hline None & None & None & None & Ins & Ins & Ins & Ins & Ins \\
\hline Typical & Typical & Typical & Typical & Typical & Typical & Typical & Typical & Typical \\
(Waste) & (Waste) & (Waste) & (Waste) & (Waste) & (Waste) & (Waste) & (Waste) & (Waste) \\
\hline & & & & & & & & \\
\hline 2,351 & 3,457 & 2,892 & 4,352 & 1,984 & 3,025 & 2,328 & 3,408 & 2,865 \\
\hline 18,705 & 29,121 & 19,734 & 31,639 & 17,504 & 28,092 & 18,486 & 28,651 & 19,515 \\
\hline 21,316 & 33,311 & 21,927 & 35,130 & 21,004 & 33,741 & 21,205 & 33,002 & 21,815 \\
\hline 1,994 & 3,100 & 2,478 & 3,939 & 1,684 & 2,725 & 1,971 & 3,051 & 2,451 \\
\hline 353.3 & 353.1 & 410.4 & 409.1 & 296.5 & 296.3 & 353.4 & 353.1 & 410.4 \\
\hline 141.6 & 236.3 & 217.1 & 396.8 & 114.4 & 200.0 & 143.1 & 235.0 & 217.4 \\
\hline 3,961 & 5,974 & 4,268 & 6,976 & 3,424 & 5,107 & 3,789 & 5,557 & 4,094 \\
\hline 382.5 & 554.4 & 428.4 & 622.7 & 301.6 & 434.2 & 346.0 & 486.0 & 387.2 \\
\hline & & & & & & & & \\
\hline 524.1 & 790.7 & 645.5 & $1,019.5$ & 416.1 & 634.2 & 489.1 & 721.0 & 604.6 \\
\hline 1,473 & 2,313 & 1,836 & 2,923 & 1,272 & 2,094 & 1,485 & 2,334 & 1,850 \\
\hline $62.7 \%$ & $66.9 \%$ & $63.5 \%$ & $67.2 \%$ & $64.1 \%$ & $69.2 \%$ & $63.8 \%$ & $68.5 \%$ & $64.6 \%$ \\
\hline $16.3 \%$ & $16.0 \%$ & $14.8 \%$ & $14.3 \%$ & $15.2 \%$ & $14.4 \%$ & $14.9 \%$ & $14.3 \%$ & $13.5 \%$ \\
\hline $6.0 \%$ & $6.8 \%$ & $7.5 \%$ & $9.1 \%$ & $5.8 \%$ & $6.6 \%$ & $6.1 \%$ & $6.9 \%$ & $7.6 \%$ \\
\hline $15.0 \%$ & $10.2 \%$ & $14.2 \%$ & $9.4 \%$ & $14.9 \%$ & $9.8 \%$ & $15.2 \%$ & $10.4 \%$ & $14.3 \%$ \\
\hline $21.2 \%$ & $20.5 \%$ & $21.6 \%$ & $22.0 \%$ & $19.6 \%$ & $18.2 \%$ & $20.5 \%$ & $19.4 \%$ & $21.0 \%$ \\
\hline $26.9 \%$ & $25.8 \%$ & $27.6 \%$ & $28.3 \%$ & $24.3 \%$ & $22.2 \%$ & $25.8 \%$ & $24.1 \%$ & $26.5 \%$ \\
\hline $22.3 \%$ & $22.9 \%$ & $22.3 \%$ & $23.4 \%$ & $21.0 \%$ & $21.0 \%$ & $21.0 \%$ & $21.2 \%$ & $21.1 \%$ \\
\hline $35.6 \%$ & $34.2 \%$ & $35.2 \%$ & $34.9 \%$ & $32.7 \%$ & $30.3 \%$ & $32.9 \%$ & $30.9 \%$ & $32.7 \%$ \\
\hline
\end{tabular}




\begin{tabular}{|c|c|c|c|c|c|c|c|c|}
\hline 96 & 97 & 98 & 99 & 100 & 101 & 102 & 103 & 104 \\
\hline Atlanta & Phoenix & Phoenix & Houston & Houston & Atlanta & Atlanta & Phoenix & Phoenix \\
\hline 4 & 2 & 4 & 2 & 4 & 2 & 4 & 2 & 4 \\
\hline $\begin{array}{l}\text { Home } \\
\text { Run }\end{array}$ & Hybrid & Hybrid & Hybrid & Hybrid & Hybrid & Hybrid & Hybrid & Hybrid \\
\hline Ins & None & None & None & None & None & None & Ins & Ins \\
\hline $\begin{array}{l}\text { Typical } \\
\text { (Waste) }\end{array}$ & Compact & Compact & Compact & Compact & Compact & Compact & Compact & Compact \\
\hline 4,293 & 1,871 & 2,870 & 2,192 & 3,226 & 2,708 & 4,065 & 1,850 & 2,827 \\
\hline 31,152 & 16,362 & 26,560 & 17,229 & 26,978 & 18,252 & 29,343 & 16,140 & 26,095 \\
\hline 34,811 & 19,996 & 32,385 & 20,036 & 31,473 & 20,628 & 33,118 & 19,861 & 32,072 \\
\hline 3,880 & 1,571 & 2,570 & 1,835 & 2,869 & 2,294 & 3,652 & 1,550 & 2,527 \\
\hline 409.2 & 296.6 & 296.3 & 353.5 & 353.2 & 410.6 & 409.5 & 296.6 & 296.4 \\
\hline 392.0 & 86.0 & 152.4 & 106.6 & 173.1 & 163.4 & 295.4 & 83.1 & 145.0 \\
\hline 6,546 & 2,146 & 3,410 & 2,374 & 3,705 & 2,658 & 4,520 & 1,986 & 3,050 \\
\hline 544.1 & 183.8 & 283.9 & 209.0 & 316.4 & 238.5 & 352.7 & 160.9 & 238.7 \\
\hline 936.1 & 269.8 & 436.2 & 315.6 & 489.5 & 401.9 & 648.1 & 244.0 & 383.7 \\
\hline 2,948 & 1,305 & 2,138 & 1,523 & 2,383 & 1,895 & 3,007 & 1,310 & 2,147 \\
\hline $68.7 \%$ & $69.7 \%$ & $74.5 \%$ & $69.5 \%$ & $73.9 \%$ & $70.0 \%$ & $74.0 \%$ & $70.8 \%$ & $75.9 \%$ \\
\hline $12.7 \%$ & $9.8 \%$ & $9.9 \%$ & $9.5 \%$ & $9.8 \%$ & $8.8 \%$ & $8.7 \%$ & $8.7 \%$ & $8.4 \%$ \\
\hline $9.1 \%$ & $4.6 \%$ & $5.3 \%$ & $4.9 \%$ & $5.4 \%$ & $6.0 \%$ & $7.3 \%$ & $4.5 \%$ & $5.1 \%$ \\
\hline $9.5 \%$ & $15.8 \%$ & $10.3 \%$ & $16.1 \%$ & $10.9 \%$ & $15.2 \%$ & $10.1 \%$ & $16.0 \%$ & $10.5 \%$ \\
\hline $21.0 \%$ & $13.1 \%$ & $12.8 \%$ & $13.8 \%$ & $13.7 \%$ & $14.6 \%$ & $15.4 \%$ & $12.3 \%$ & $11.7 \%$ \\
\hline $26.6 \%$ & $15.1 \%$ & $14.7 \%$ & $16.0 \%$ & $15.9 \%$ & $17.0 \%$ & $18.2 \%$ & $14.0 \%$ & $13.2 \%$ \\
\hline $21.8 \%$ & $14.4 \%$ & $15.2 \%$ & $14.4 \%$ & $15.2 \%$ & $14.8 \%$ & $15.9 \%$ & $13.2 \%$ & $13.6 \%$ \\
\hline $31.8 \%$ & $20.7 \%$ & $20.4 \%$ & $20.7 \%$ & $20.5 \%$ & $21.2 \%$ & $21.6 \%$ & $18.6 \%$ & $17.9 \%$ \\
\hline
\end{tabular}




\begin{tabular}{c|c|c|c|c|c|c|c|c}
\hline 105 & 106 & 107 & 108 & 109 & 110 & 111 & 112 & 113 \\
\hline Houston & Houston & Atlanta & Atlanta & Phoenix & Phoenix & Houston & Houston & Atlanta \\
\hline 2 & 4 & 2 & 4 & 2 & 4 & 2 & 4 & 2 \\
\hline Hybrid & Hybrid & Hybrid & Hybrid & Hybrid & Hybrid & Hybrid & Hybrid & Hybrid \\
\hline & & & & & & & & \\
\hline Ins & Ins & Ins & Ins & None & None & None & None & None \\
\hline Compact & Compact & Compact & Compact & $\begin{array}{c}\text { Typical } \\
\text { (Waste) }\end{array}$ & $\begin{array}{c}\text { Typical } \\
\text { (Waste) }\end{array}$ & $\begin{array}{c}\text { Typical } \\
\text { (Waste) }\end{array}$ & $\begin{array}{c}\text { Typical } \\
\text { (Waste) }\end{array}$ & $\begin{array}{c}\text { Typical } \\
\text { (Waste) }\end{array}$ \\
\hline & & & & & & & & \\
\hline 2,168 & 3,179 & 2,678 & 4,004 & 1,966 & 3,003 & 2,307 & 3,380 & 2,846 \\
\hline 16,994 & 26,517 & 18,011 & 28,853 & 17,312 & 27,873 & 18,307 & 28,409 & 19,367 \\
\hline 19,888 & 31,157 & 20,465 & 32,758 & 20,768 & 33,452 & 20,963 & 32,684 & 21,612 \\
\hline 1,811 & 2,822 & 2,264 & 3,591 & 1,666 & 2,703 & 1,950 & 3,023 & 2,432 \\
\hline 353.5 & 353.3 & 410.6 & 409.5 & 296.5 & 296.3 & 353.3 & 353.1 & 410.4 \\
\hline 103.3 & 165.8 & 157.1 & 280.4 & 112.3 & 196.0 & 140.4 & 226.0 & 213.3 \\
\hline 2,208 & 3,340 & 2,470 & 4,112 & 3,120 & 4,738 & 3,506 & 5,174 & 3,845 \\
\hline 183.1 & 266.8 & 208.7 & 295.5 & 278.5 & 407.0 & 322.1 & 457.5 & 364.3 \\
\hline & & & & & & & & \\
\hline 286.4 & 432.6 & 365.8 & 575.8 & 390.8 & 603.0 & 462.5 & 683.4 & 577.6 \\
\hline 1,528 & 2,393 & 1,901 & 3,019 & 1,279 & 2,104 & 1,491 & 2,343 & 1,858 \\
\hline $70.5 \%$ & $75.3 \%$ & $71.0 \%$ & $75.4 \%$ & $65.0 \%$ & $70.1 \%$ & $64.6 \%$ & $69.3 \%$ & $65.3 \%$ \\
\hline $8.4 \%$ & $8.4 \%$ & $7.8 \%$ & $7.4 \%$ & $14.2 \%$ & $13.6 \%$ & $14.0 \%$ & $13.5 \%$ & $12.8 \%$ \\
\hline $4.8 \%$ & $5.2 \%$ & $5.9 \%$ & $7.0 \%$ & $5.7 \%$ & $6.5 \%$ & $6.1 \%$ & $6.7 \%$ & $7.5 \%$ \\
\hline $16.3 \%$ & $11.1 \%$ & $15.3 \%$ & $10.2 \%$ & $15.1 \%$ & $9.9 \%$ & $15.3 \%$ & $10.4 \%$ & $14.4 \%$ \\
\hline $13.0 \%$ & $12.6 \%$ & $13.7 \%$ & $14.3 \%$ & $18.0 \%$ & $17.0 \%$ & $19.2 \%$ & $18.2 \%$ & $19.9 \%$ \\
\hline $14.9 \%$ & $14.4 \%$ & $15.9 \%$ & $16.6 \%$ & $22.0 \%$ & $20.5 \%$ & $23.7 \%$ & $22.3 \%$ & $24.8 \%$ \\
\hline $13.2 \%$ & $13.6 \%$ & $13.7 \%$ & $14.4 \%$ & $19.9 \%$ & $20.1 \%$ & $20.0 \%$ & $20.2 \%$ & $20.3 \%$ \\
\hline $18.7 \%$ & $18.1 \%$ & $19.2 \%$ & $19.1 \%$ & $30.6 \%$ & $28.7 \%$ & $31.0 \%$ & $29.2 \%$ & $31.1 \%$ \\
\hline
\end{tabular}




\begin{tabular}{c|c|c|c|c|c|c}
\hline 114 & 115 & 116 & 117 & 118 & 119 & 120 \\
\hline Atlanta & Phoenix & Phoenix & Houston & Houston & Atlanta & Atlanta \\
\hline 4 & 2 & 4 & 2 & 4 & 2 & 4 \\
\hline Hybrid & Hybrid & Hybrid & Hybrid & Hybrid & Hybrid & Hybrid \\
\hline & & & & & & \\
\hline None & Ins & Ins & Ins & Ins & Ins & Ins \\
\hline Typical & Typical & Typical & Typical & Typical & Typical & Typical \\
(Waste) & (Waste) & (Waste) & (Waste) & (Waste) & (Waste) & (Waste) \\
\hline & & & & & & \\
\hline 4,260 & 1,945 & 2,959 & 2,285 & 3,334 & 2,821 & 4,204 \\
\hline 30,902 & 17,091 & 27,410 & 18,093 & 27,959 & 19,154 & 30,439 \\
\hline 34,471 & 20,628 & 33,121 & 20,831 & 32,358 & 21,482 & 34,142 \\
\hline 3,847 & 1,645 & 2,660 & 1,928 & 2,977 & 2,407 & 3,792 \\
\hline 409.2 & 296.5 & 296.3 & 353.4 & 353.2 & 410.5 & 409.3 \\
\hline 376.8 & 111.9 & 192.5 & 140.6 & 223.8 & 212.6 & 371.2 \\
\hline 6,143 & 2,941 & 4,328 & 3,336 & 4,771 & 3,673 & 5,733 \\
\hline 514.5 & 252.7 & 356.0 & 293.4 & 401.4 & 331.5 & 450.2 \\
\hline & & & & & & \\
\hline 891.3 & 364.7 & 548.5 & 434.0 & 625.2 & 544.1 & 821.4 \\
\hline 2,959 & 1,284 & 2,115 & 1,498 & 2,356 & 1,866 & 2,974 \\
\hline $69.5 \%$ & $66.0 \%$ & $71.5 \%$ & $65.5 \%$ & $70.7 \%$ & $66.2 \%$ & $70.7 \%$ \\
\hline $12.1 \%$ & $13.0 \%$ & $12.0 \%$ & $12.8 \%$ & $12.0 \%$ & $11.8 \%$ & $10.7 \%$ \\
\hline $8.8 \%$ & $5.8 \%$ & $6.5 \%$ & $6.2 \%$ & $6.7 \%$ & $7.5 \%$ & $8.8 \%$ \\
\hline $9.6 \%$ & $15.2 \%$ & $10.0 \%$ & $15.5 \%$ & $10.6 \%$ & $14.6 \%$ & $9.7 \%$ \\
\hline $19.9 \%$ & $17.2 \%$ & $15.8 \%$ & $18.4 \%$ & $17.1 \%$ & $19.2 \%$ & $18.8 \%$ \\
\hline $24.8 \%$ & $20.8 \%$ & $18.7 \%$ & $22.6 \%$ & $20.6 \%$ & $23.7 \%$ & $23.2 \%$ \\
\hline $20.9 \%$ & $18.7 \%$ & $18.5 \%$ & $19.0 \%$ & $18.8 \%$ & $19.3 \%$ & $19.5 \%$ \\
\hline $30.1 \%$ & $28.4 \%$ & $25.9 \%$ & $29.0 \%$ & $26.5 \%$ & $29.2 \%$ & $27.6 \%$ \\
\hline & & & & & & \\
\hline
\end{tabular}




\begin{tabular}{|c|c|c|c|c|}
\hline 121 & 122 & 123 & 124 & Parametric Options for Run ID \\
\hline Atlanta & Atlanta & Atlanta & Atlanta & Climate \\
\hline 2 & 4 & 2 & 4 & Occupants \\
\hline \multirow[t]{2}{*}{$\begin{array}{l}\text { Trunk \& } \\
\text { Branch }\end{array}$} & $\begin{array}{l}\text { Trunk \& } \\
\text { Branch }\end{array}$ & $\begin{array}{l}\text { Demand } \\
\text { Recirc }\end{array}$ & $\begin{array}{l}\text { Demand } \\
\text { Recirc }\end{array}$ & Distribution Type \\
\hline & & $\begin{array}{l}\text { Long run- } \\
\text { outs }\end{array}$ & $\begin{array}{l}\text { Long run- } \\
\text { outs }\end{array}$ & Recirculation Type \\
\hline None & None & None & None & Insulation \\
\hline \multirow[t]{2}{*}{ Compact } & Compact & Compact & Compact & Plumbing Practice \\
\hline & & & & Annual Results \\
\hline 2,688 & 4,039 & 2,976 & 4,360 & Water Heater Energy Use (kWh) \\
\hline 18,115 & 29,177 & 17,232 & 27,679 & Hot Water Draw (gal) \\
\hline 20,399 & 32,788 & 19,302 & 31,012 & Total Water Use (gal) \\
\hline 2,274 & 3,626 & 2,561 & 3,945 & Energy Delivered (kWh) \\
\hline 410.6 & 409.4 & 410.9 & 411.3 & Tank Losses (kWh) \\
\hline 168.6 & 315.8 & 166.4 & 282.2 & Use Point Wasted Energy (kWh) \\
\hline 2,555 & 4,518 & 2,429 & 4,029 & Wasted Hot Water (gal) \\
\hline \multirow[t]{2}{*}{244.9} & 360.8 & 625.9 & 839.5 & Pipe Loss, All (kWh) \\
\hline & & 176.1 & 212.3 & Recirc Losses (kWh) \\
\hline 413.5 & 676.5 & 792.3 & $1,121.7$ & Total Distribution Losses (kWh) \\
\hline 1,864 & 2,953 & 1,772 & 2,827 & Total Useful Energy (kWh) \\
\hline $69.3 \%$ & $73.1 \%$ & $59.6 \%$ & $64.8 \%$ & Useful Energy ( $\%$ of water heater energy use) \\
\hline $9.1 \%$ & $8.9 \%$ & $21.0 \%$ & $19.3 \%$ & Pipe Losses ( $\%$ of water heater energy use) \\
\hline $6.3 \%$ & $7.8 \%$ & $5.6 \%$ & $6.5 \%$ & Wasted Energy ( $\%$ of water heater energy use) \\
\hline $15.3 \%$ & $10.1 \%$ & $13.8 \%$ & $9.4 \%$ & $\begin{array}{c}\text { Water Heater Losses (\% of water heater energy } \\
\text { use) }\end{array}$ \\
\hline $14.1 \%$ & $15.5 \%$ & $14.1 \%$ & $14.6 \%$ & Water Waste (\% of total hot water) \\
\hline $16.4 \%$ & $18.3 \%$ & $16.4 \%$ & $17.0 \%$ & Wasted Water (\% of useful water delivered) \\
\hline $15.4 \%$ & $16.8 \%$ & $26.6 \%$ & $25.7 \%$ & $\begin{array}{c}\text { Distribution Losses ( } \% \text { of water heater energy } \\
\text { use) }\end{array}$ \\
\hline $22.2 \%$ & $22.9 \%$ & $44.7 \%$ & $39.7 \%$ & $\begin{array}{c}\text { Distribution Losses (\% of useful energy } \\
\text { delivered) }\end{array}$ \\
\hline
\end{tabular}




\section{Appendix B. Plumbing Layouts}

Table 5. List of Plumbing Layout Variations

\begin{tabular}{|c|c|c|c|}
\hline $\begin{array}{l}\text { Distribution } \\
\text { Types }\end{array}$ & $\begin{array}{c}\text { Water Heater Location } \\
\text { Options }\end{array}$ & Line Sizes & Insulation \\
\hline $\begin{array}{c}\text { Trunk and } \\
\text { Branch }\end{array}$ & $\begin{array}{l}\text { Remote location: } 15-\mathrm{ft} \\
\text { run } \\
\text { Central located: } 4.5-\mathrm{ft} \\
\text { run }\end{array}$ & $\begin{array}{l}\text { Trunk and main feed, } 3 / 4 \text { in. } \\
\text { Use-points, } 1 / 2 \text { in. }\end{array}$ & $\begin{array}{c}\text { No insulation: all lines } \\
\text { uninsulated } \\
\text { Insulated: all lines } \\
\text { insulated }\end{array}$ \\
\hline Home Run & $\begin{array}{l}\text { Waste: } 15-\mathrm{ft} \text { run of } 1 \mathrm{in} \text {. } \\
\text { to manifold } \\
\text { Compact: } 4.5 \text {-ft run of } 3 / 4 \\
\text { in. to manifold }\end{array}$ & $\begin{array}{l}\text { Waste: all lines } 1 / 2 \text { in. } \\
\text { Compact: sinks and dishwasher } \\
3 / 8 \text { in., all others } 1 / 2 \text { in. }\end{array}$ & $\begin{array}{l}\text { Waste: insulate to } \\
\text { manifold } \\
\text { Compact: insulate } \\
\text { everything }\end{array}$ \\
\hline Hybrid & $\begin{array}{l}\text { Waste: } 15 \text {-ft run of } 1 \text {-in. } \\
\text { to manifold } \\
\text { Compact: } 4.5 \text {-in. run of } \\
\text { 3/4-in. to manifold }\end{array}$ & $\begin{array}{l}\text { Waste: all lines } 1 / 2 \text { in. } \\
\text { Compact: sinks and dishwasher } \\
3 / 8 \text { in., all others } 1 / 2 \text { in. }\end{array}$ & $\begin{array}{l}\text { Waste: insulate to } \\
\text { manifold } \\
\text { Compact: insulate } \\
\text { everything }\end{array}$ \\
\hline Recirculation & $\begin{array}{l}\text { Centrally located, } 4.5-\mathrm{ft} \\
\text { run of } 1 \text { in. to start of } \\
\text { loop }\end{array}$ & $\begin{array}{l}\text { Recirc line: } 1 \text { in. supply, } 3 / 4 \text { in. } \\
\text { return } \\
\text { Use-points: } 1 / 2 \text { in. } \\
\text { Long Runouts: recirc loop is far } \\
\text { from use-points } \\
\text { Short Runouts: recirc loop is } \\
\text { within } 15 \mathrm{ft} \text { from all use points }\end{array}$ & All lines insulated \\
\hline
\end{tabular}




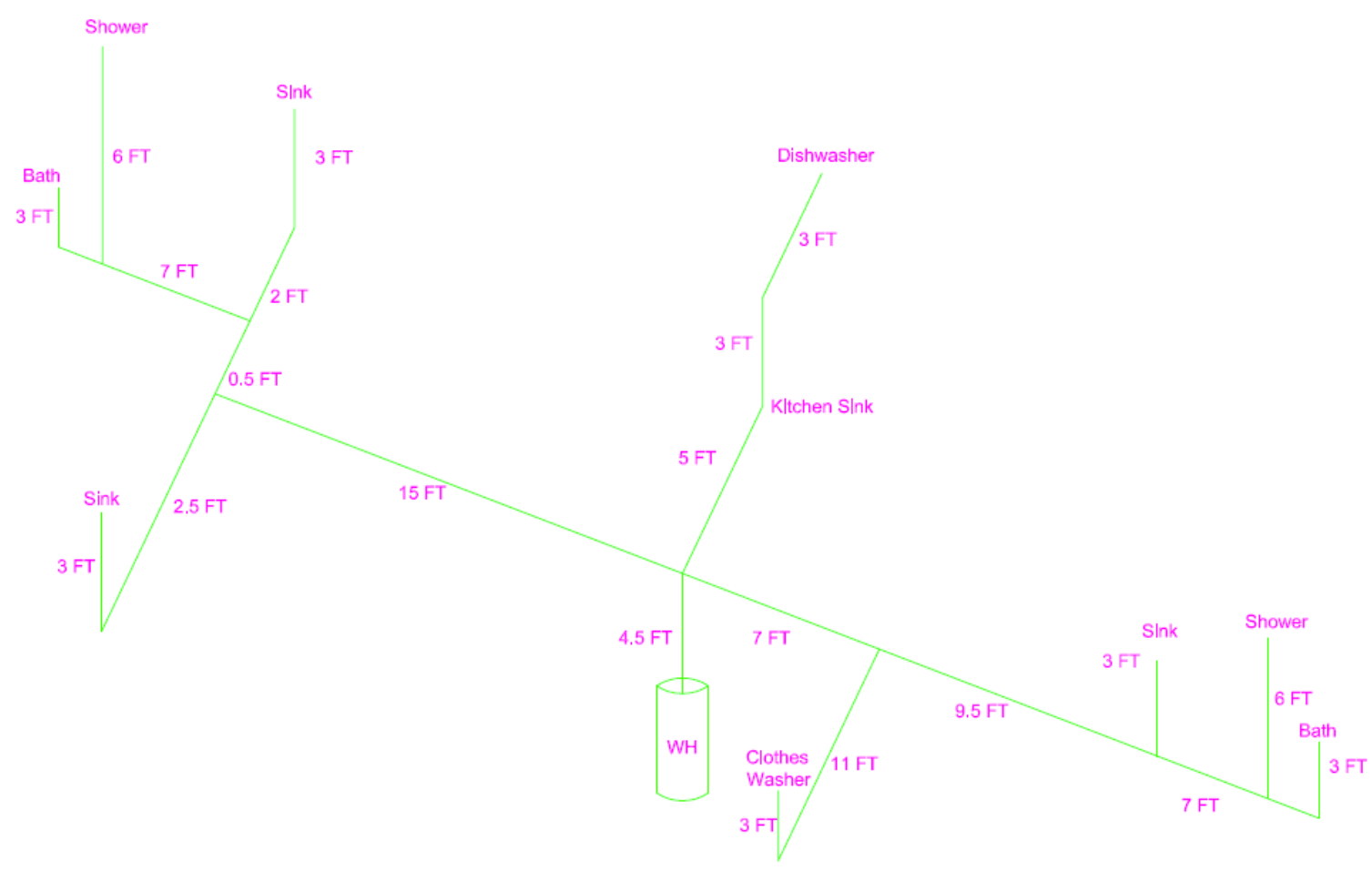

Figure 12. Trunk and branch distribution layout, basement

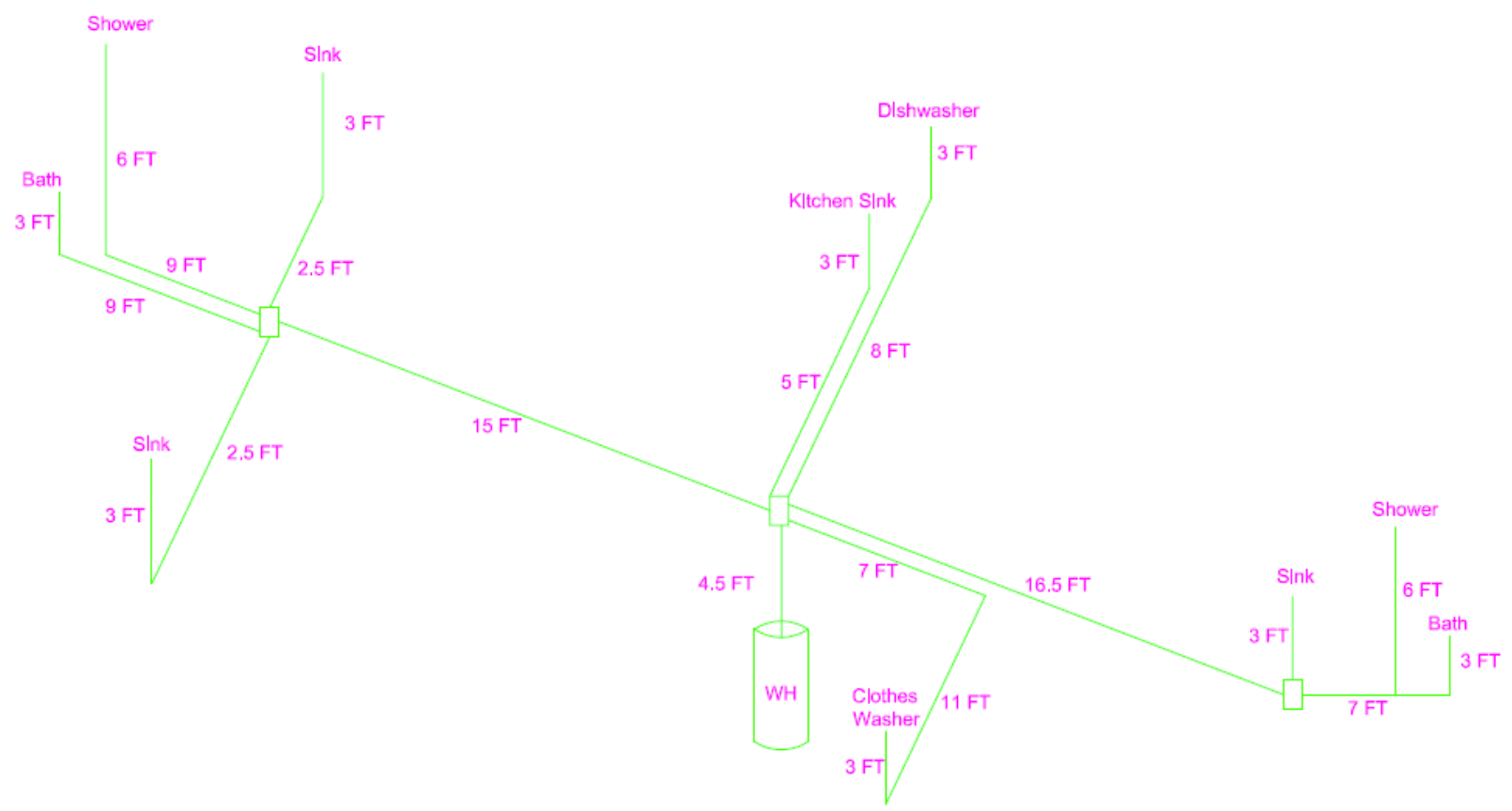

Figure 13. Hybrid distribution layout, basement 


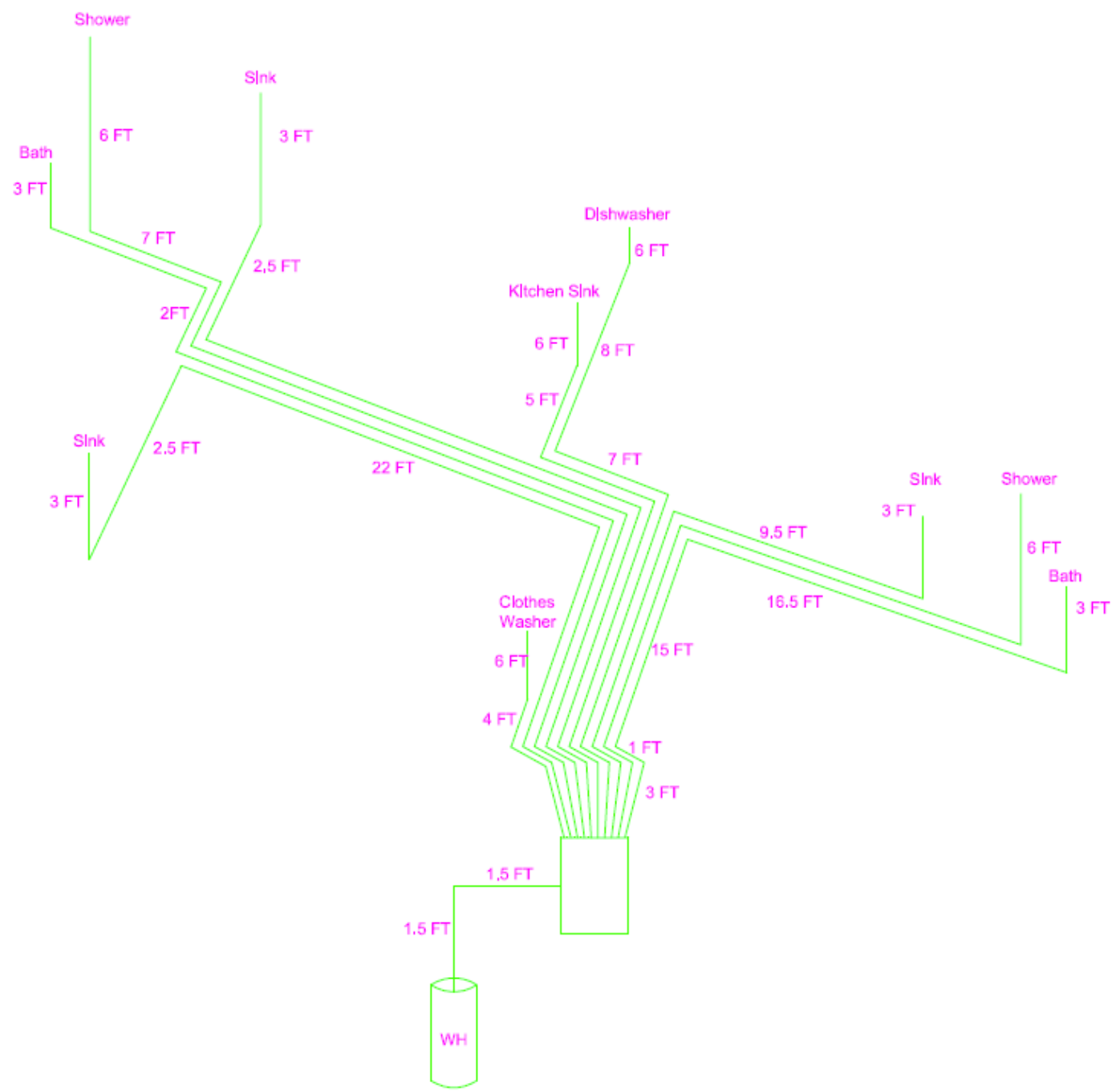

Figure 14. Home run distribution layout, basement 


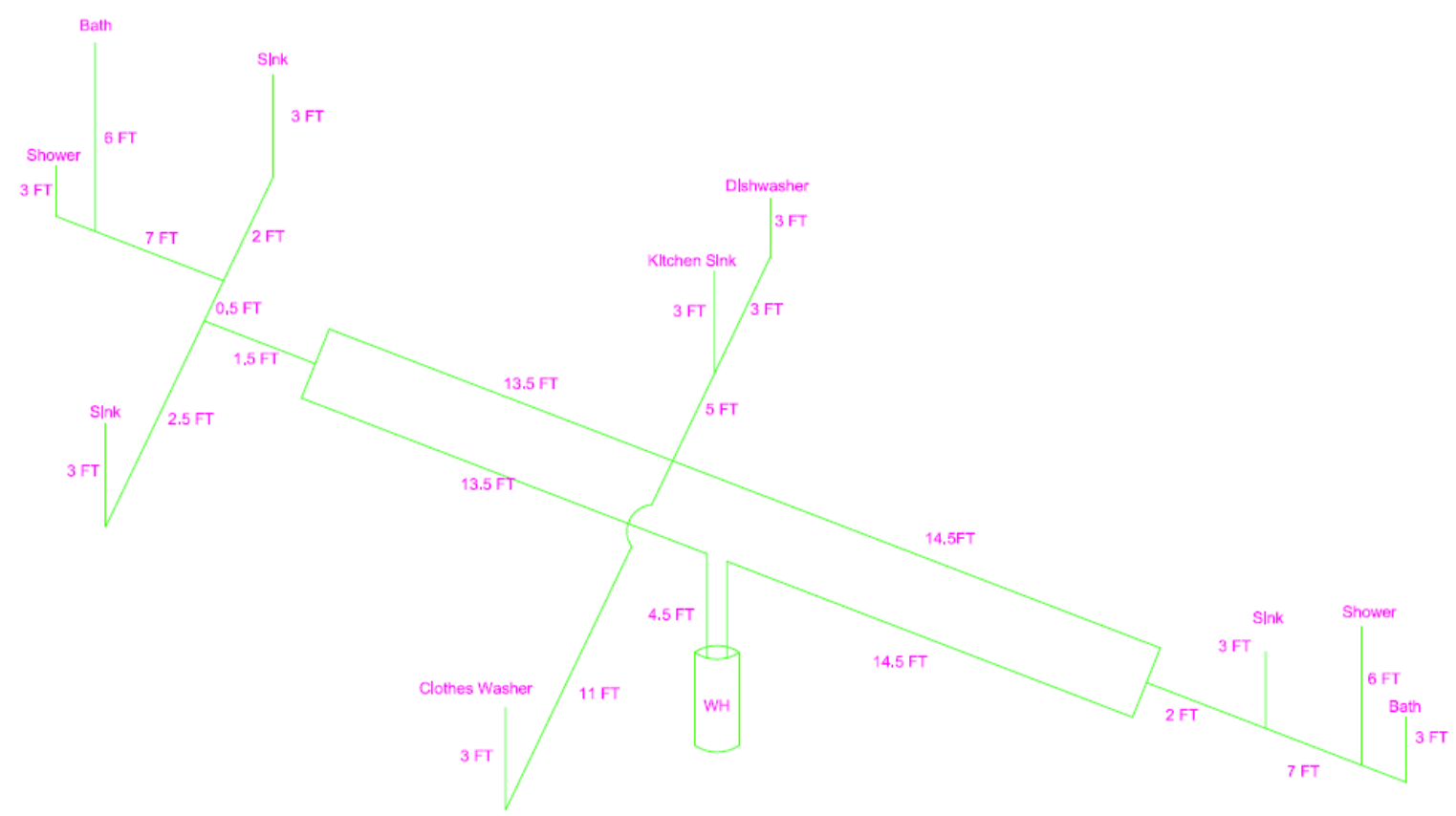

Figure 15. Short run-out recirculation distribution layout, basement

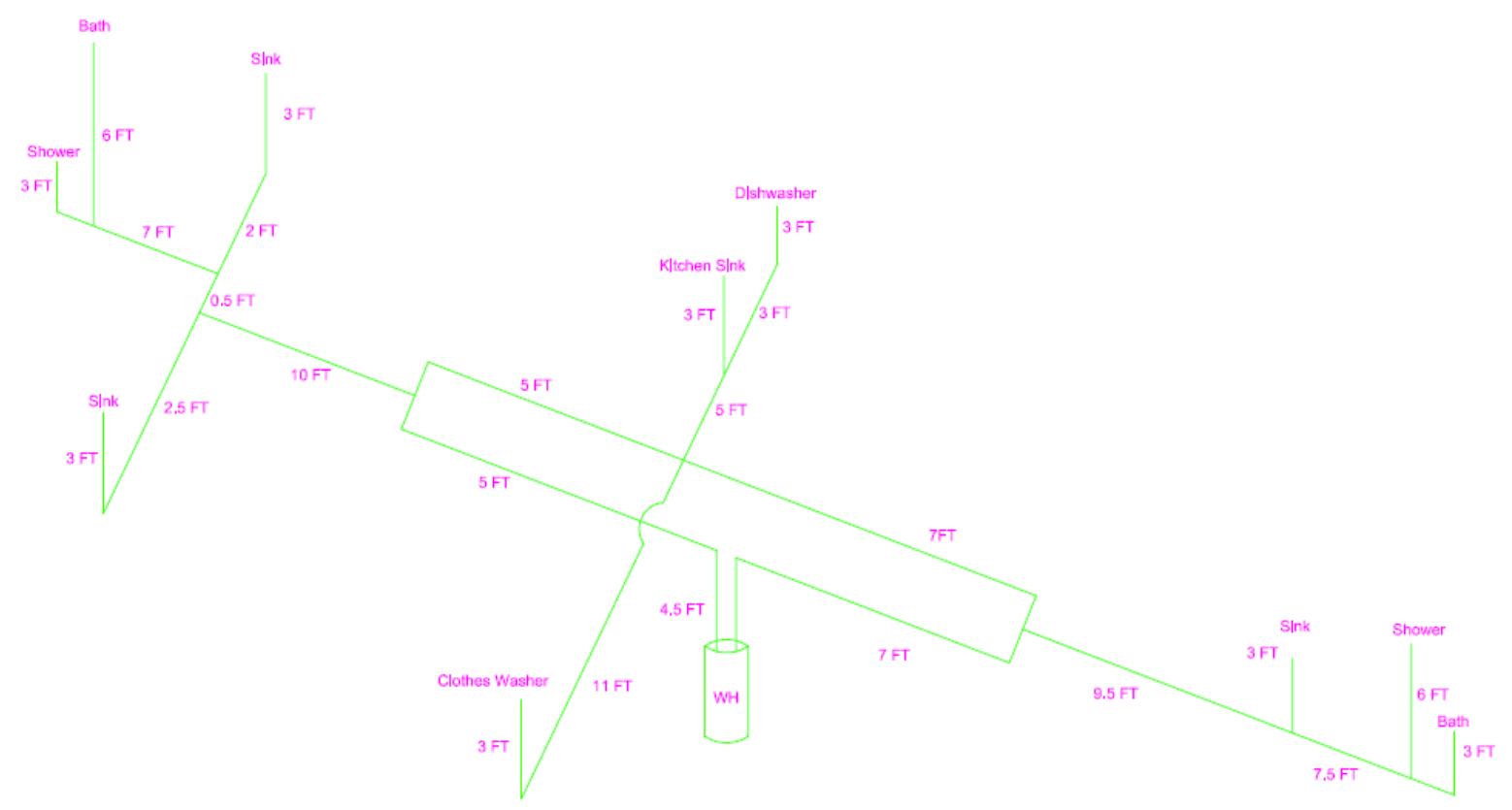

Figure 16. Long run-out recirculation distribution layout, basement 
